
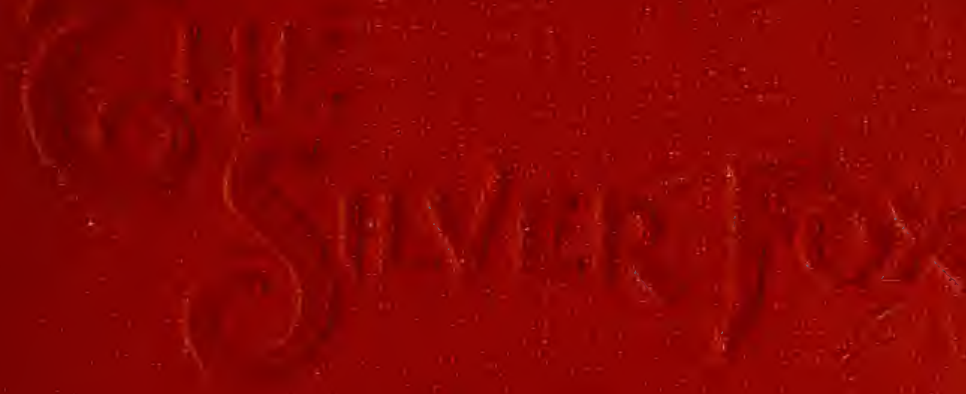


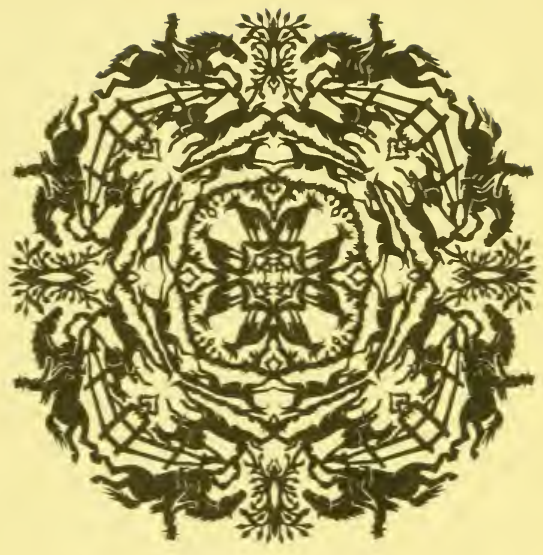

JOHN A.SEAVERNS 

THE SILVER FOX 
STORIES AND SKETCHES OF IRISH LIFE

By E. E. Somerville and Martin Ross.

SOME EXPERIENCES OF AN IRISH R.M.

With 3 I Illustrations by E. CE. SOMERville. Crown 8vo, 35. 6d.

FURTHER EXPERIENCES OF AN IRISH R.M.

With 35 Illustrations by E. CE. Somerville.

Crown 8vo, 3s. 6d.

ALL ON THE IRISH SHORE.

With Io Illustrations by E. CE. SoMerville.

Crown 8vo, 3s. 6d.

SOME IRISH YESTERDAYS.

With 5 I Illustrations by E. CE. SOMERville.

Crown 8vo, 3s. 6d.

AN IRISH COUSIN.

Crown 8vo, 3s. 6d.

THE REAL CHARLOTTE. Crown 8vo, 3s. 6d.

THE SILVER FOX.

Crown 8vo, 3s. 6d.

THE DISCONTENTED LITTLE

ELEPHANT: A Cautionary Story.

Written and Illustrated by E. CE. SOMERvilie.

With 8 Coloured Pictures and 16 Uncoloured pages. Crown 4 to. $\left(10 \frac{1}{2} \times 7 \frac{9}{\frac{9}{4}}\right.$ in.). Is. $6 d$. net.

LONGMANS, GREEN, AND CO.

39 PATERNOSTER ROW, LONDON NEW YORK, BOMBAY AND CALCUTTA 


\section{THE SILVER FOX}

BY

E. CE. SOMERVILLE AND MARTIN ROSS

AUTHOR8 Or

'AN IRISH COUSIN,' 'the real charlotte,' 'SOME EXPERIENCES

OF AN IRISH R.M.;' 'ALL ON THE IRISH SHORE,' ETC., ETC.

Afew Fmpresoion

LONGMANS, GREEN, AND CO.

39 PATERNOSTER ROW, LONDON

NEW YORK, BOMBAY AND CALCUTTA

1912 


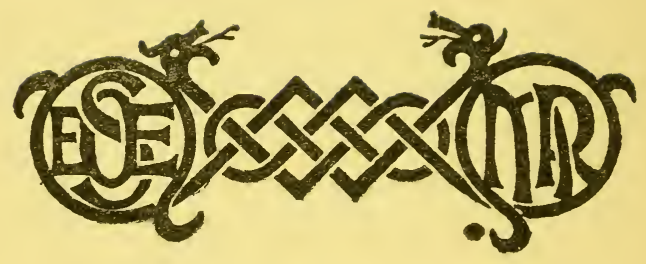

First Edition published by Messrs. Lawrence \& Bullen, Limited, 1898. Transferred to Longmans, Green \& Co., 1900. Reprinted, January 1902 , and, with corrections, January 1904 and August I9I 2 


\section{THE SILVER FOX}

\section{CHAPTER I}

Lady Susan had never been so hungry in her life. So, for the sixth time, she declared between loud and unbridled yawns. She worked her chair across the parquet towards the fire-place, dragging the hearthrug into folds in her progress, and put her large and well-shod feet on the fender.

"What a beast of a fire! When you've quite done with it, Bunny, I shouldn't mind seeing it just the same. You are a selfish thing!"

In obedience to this rebuke Major Bunbury moved an inch or two to one side.

"I'm not as selfish as you are," he said, 
with agreeable simplicity. "Miss Morris can't see anything but your boots."

"Oh, she likes seeing boots," replied Lady Susan, establishing one on the hob. "They don't have.'em in Ireland, do they, Slaney!"

It was obviously the moment for Miss Morris to say something brilliant, but she let the opportunity slip. Perhaps she was hampered by the consciousness that her boots had been made in an Irish country town. She got red. She did not know that it was becoming to her to get red. Finding no more appropriate retort, she laughed, and pushing back her chair, walked over to the window. What she looked out on was the lawn at Hurlingham, covered smoothly and desolately with snow; a line of huddled, white hummocks of ice, moving very slowly across the middle distance, represented the River Thames; down to the right, five or six skaters glided on the black and serpentine curves of a little lake-they looked like marionettes sliding 
along a wire. Even at that distance they seemed to Slaney over-dressed and artificial. No doubt they were screaming inanities to each other, as were these other English idiots in the room behind her. How ineffably stupid they were, and how shy and provincial they made her feel! How could Hugh have married into such a pack?

One of the double doors at the end of the room opened, and a small, dark man appeared.

"Awfully sorry to have kept you all waiting," he said abjectly. "I'm afraid it's a bad business; they say that there's nothing to be had here on Sundays at this time of year, unless it's ordered beforehand."

"Oh Lord!" ejaculated Lady Susan, bringing her foot and the shovel down with a crash. "Do you mean to say there's nothing to eat?"

"It's not quite as bad as that, but precious nearly," he replied, looking at her so deplorably that Slaney felt inclined to laugh. 
"We're going to have some of the waiter's dinner. It's a leg of mutton, and he says he don't think it's quite boiled yet, but I said we wouldn't wait."

Lady Susan seized Major Bunbury's hand, and pulled herself out of her chair. She was stalwart and tall, and her dress fitted beautifully. With a whisk and rustle of silk petticoats she was across the room and caught Miss Morris by the arm.

"Worry, worry, worry! Sess, sess, sess!" she said, with a sufficiently fortunate imitation of her father's kennel huntsman. "Come on and eat raw leg of mutton! I hope the waiter likes onion sauce!"

In the dining-room a genial fire was blazing; a soft and rich-coloured carpet glowed on the floor; the atmosphere was of old-fashioned comfort; there was a desirable smell of fried potatoes. The party sank into their places at an oval table, and to each was administered a plateful of pink mutton that grew rosier at every slice. Captain Hugh French, late of the - th 
Hussars, looked round upon his guests, and felt that champagne was the only reparation in his power.

"I fecl it's all my fault bringing you people down here to starve. You'll have to take it out in drink," he said helplessly.

The words were addressed to the company, but his brown eyes, that were like the eyes of a good small dog, addressed themselves to those of his wife. Slaney, following them, wondered whether he could help seeing the black line frankly drawn along the edge of Lady Susan's lower eyelids. The white glare from the snow showed it unsparingly, as she looked at her husband over the rim of the champagne glass from which she was drinking.

"Yes, darling, you're a silly little thing," she said blandly; "I always said that spill had given you softening of the brain."

"What spill ?" asked Slaney. It was almost the first time she had spoken. She had sat, inwardly scornful and outwardly shy, in the midst of conversation whose 
knack she could not catch, and whose pur. port she thought either babyish or vulgar. There must be an English and an Irish form of humour, so at least it seemed to Slaney, as she listened with the intolerance of the clever provincial to Lady Susan's loud and ready laugh. Hugh, at all events, was not, she thanked Heaven, humorous in either manner. She found herself less of a fool when she was talking to Hugh.

"I'm afraid you don't take much interest in your cousin's misfortunes, Slaney," he said. "Didn't you know that I was smashed up at Bangalore last spring, playing polo? I was trying to 'ride off' this great brute," indicating Major Bunbury, "and I got the worst of it. I was in hospital for a month, and grew a thundering big black beard. Couldn't shave for six weeks."

"Don't make me sick," said Lady Susan, beginning heartily on biscuits and cheese. " If I'd known that in time I wouldn't have married you. A little man with a beard's 
like a cob with a long tail. Couldn't do with you if you'd a long tail, Hughie."

"I'm goin' to grow another when we get down to French's Court," retorted Hughie. "I shan't have anything else to do there. What on earth do you do with yourself at Letter Kyle, Slaney?"

"Do you grow a beard, Slaney?" shouted Lady Susan, with her mouth full of biscuit. "If $\Gamma m$ bored over there I shall just dye my hair again. How do you like it now, Bunny? I got it done in Paris on our way through. I think it might be a bit redder."

"Why, it's as red as a fox now," said Major Bunbury, regarding it critically.

"Talking of foxes," put in Slaney, endeavouring to be genial, "they all expect Hugh to start the hounds again when he comes over. That will give you something to do, Hugh."

"Tally ho!" uttered Major Bunbury, with a subdued whoop. "That's a rippin' good notion. I'll come over and whip for you, Hughie." 
"No, you won't!" cried Lady Susan. "I'll whip for him myself; but I don't believe he knows anything about it-does he, Bunny?"

"Oh dear, no!" replied Major Bunbury, with elephantine sarcasm; "he's a perfect owl. Can't think why we made him carry the horn till he left the regiment-and the funny thing was that he seemed quite up to the job."

Captain French took no notice of the compliment.

"I can't imagine who the people are who want me to get up a pack there," he said, without much enthusiasm; "last time I was over there seemed to be no one in the place but the parson and the two old Miss Macarthys. They'd make a pretty sort of a hunt."

"Oh, there are a lot of farmers," replied Slaney, "and there's the police officer, and there's Mr. Glasgow, the contractor of the new railway." To her own surprise and annoyance she blushed as she spoke, and 
Major Bunbury, glancing incidentally at her, thought her almost handsome.

"Glasgow," repeated Hugh; "there was a chap called Glasgow at Eton with me. What sirt of age is this man?"

"Oh, he's young - at least, not very young-I miean he's not exactly old; but he's older than you are, Hugh," replied Slaney, with incoherence probably due to the blush; "his name is Wilfrid," she added. "I think he did say something about having been at school with you."

"That's the man. Clever sort of chap; fancies himself a bit. I remember one of my pals was a fag of his, and said he was awfully particular about his toast. $\mathrm{He}$ wants hounds, does he? Why don't he get them up for himself?"

"He's too busy; besides, he said you were the man to do it, Hugh. He said he had always heard you were a great rider, and knew all about your having won the Gold Cup at Punchestown." She was conscious of pleasure in the expounding of Mr. Glasgow. 
Lady Susan, on the contrary, began to find it a bore.

"Oh, look here, you people," she broke in, "we can't sit here all day to listen to Hughie being made more conceited than he is. Come out and skate."

She snatched Major Bunbury's plate from before him, and put it down in front of an expectant cat, flung a dinner napkin over her husband's head, and fell to arranging her fringe and veil at a looking-glass with minute care and entire disregard of the company.

As Miss Morris walked after her cousin's wife down the snowy path to the lake, she framed with a confident touch the description that she would give of her to $\mathrm{Mr}$. Glasgow. Scarcely less confidently, and with a comfortable sense of fore-knowledge of his ideas and point of view, she formulated the phrase in which he would give his opinion of Lady Susan. It was satisfactory to reflect that, though she was a failure in Lady Susan's set, she found no 
ditticulty in talking to intellectual people like Mr. Wilfred Glasgow.

A light and stinging wind blew along the ice, powdering the surface with infinitely delicate particles of snow. The graceful lawns and slopes of Hurlingham stared in blank whiteness, the evergreens stood out unnaturally dark and trim in the colourless monotony; beyond the scrape and hiss of the skates the silence was extraordinary. Slaney did not enjoy herself. The southwest of Ireland is not the climate in which to learn skating; she toiled up against the wind with aching ankles, she drifted back in front of it, and finally, in bitter resentment of her ungainly helplessness, achieved the haven of a chair. Lady Susan swung and circled, and knew that her colour was rising in a manner more becoming than the best rouge that money could buy; Major Bunbury swung assiduously after her. Hugh was cutting intricate figures far away. Slaney began thinking of the gaunt afternoon service in progress at that moment in 
the church of Letter Kyle. There would be no music because she was not there to play the harmonium; Uncle Charles would be longer and louder than ever over the responses to the Psalms now that her reproving eye was off him; Mr. Glasgow-no, she felt tolerably sure that the Sundays of her absence would not be the ones selected by Mr. Glasgow for walking over to afternoon service at Letter Kyle.

"Come along, Slaney," said Captain French, sailing down upon her with his hands extended, "I know it's poor fun for you, but you must keep at it."

They moved off together, and Slaney felt, as she often did, a glow of appreciation of Hugh's desire to make things pleasant for others. She did not notice character very much, except at the moments when it was in contact with herself. Between the manifestations of her cousin's amiability towards her she habitually thought of him as merely unintellectual. At this stage of Slaney's history intellectual people were to her as 
irrevocably severed from the others as were the sheep from the goats.

"Tell me more about this idea of the hounds," said Hugh, dodging behind the island to avoid the raking sweep of Lady Susan's advance. "What am I to hunt? Hares or foxes or a red herring?"

"Foxes, of course," replied Slaney; "there are any amount of them. Uncle Charles shot two in our wood this autumn."

"Good Lord!" ejaculated Hugh; " where does he expect to go when he dies?"

"Where do you think?" answered Slaney, with an effort to be suitably flippant; "if there's anything in the world that Uncle Charles is more convinced of than another it is that he always has moved in the highest circles, and that he always will."

Hugh laughed in his kindly, indiscriminating way.

"By the way," went on Slaney, following up a connection of ideas, "there's a curious story in the country now about a fox. Mr. Glasgow wanted gravel for the new railway, 
and bought a bit of a hillside from old Danny Quin at Cahirdreen. There was a big patch of furze there, and the men said that when the first blast went off a grey fox ran out of it and away into the hills; a sort of fox that no one had ever seen before. They say that there is an old prophecy about the bad luck that is to come when that hill is thrown into Tully Lake, and that is just what is to be done where the line crosses a corner of the lake. They believe that the fox is a witch or a fairy, and that it will bring the bad luck."

"By Jove! that's rather interesting," said Hugh, steering Slaney into a chair and subsiding into another beside her; "we'll have to kill that grey fox."

"The men say he was more a silver colour," pursued Slaney, "and Mike Driscoll told me "he thought he'd never ate another bit, afther he seen the way it legged it up the hill, an' it lashin' the tail and makin' snouts at them like a thing that'd be grinnin' and laughin'." Slaney was very successfu] 
in her rendering of Mike Driscoll, and Hugh laughed again, his ugly little falsetto laugh, and felt that Slaney was a very good fellow indeed.

Lady Susan, doing "Dutch roll," bore down upon them.

"The horrid thing was lying on my feet," she was exclaiming to Major Bunbury, whose hand she was holding at the full stretch of both their arms. "I never remembered that till this instant,-Hughie," she called to Captain French as they passed, and grasping at his chair she whirled round and came sitting on his knee- "It really was a most awful dream, darling. I had it last night when you were snoring, and it suddenly came into my head now. I thought some ghastly thing was sitting on my feet, like a dog or something, and then suddenly it turned into a whitey, silvery sort of thing, a kind of Arctic fox, and the horrid thing was smiling and showing all its teeth. My word, I was in a funk. And then it turned out to be only the hot-water bag." 
"It's all tricks, Slaney," said Hugh, "she heard what we were saying." $\mathrm{He}$ laughed and looked at Slaney, whose curious hazel-green eyes were fixed in consternation on Lady Susan. . 


\section{CHAPTER II}

Danny Quin was to be buried that afternoon. It was the third day of the wake, and his house, always dependent for light on its open door, was dark with the crowd of people inside and outside the threshold. In the corner of the kitchen, behind the brute obstruction of human beings, awkward and inert with stale drink, half-a-dozen candles made a garish night-time round the dead man. He lay with the yellow flicker on his steadfast face, a presence of extraordinary refinement and soulful trance among his late fellows. He was an old man, in his lifetime a driver of hard bargains, a teller of old tales in which his own sagacity, uprightness, and poiver of repartee were unflinchingly set forth. Here his super- 
natural pallor and tranquil lips spoke of death and resurrection to an audience whose greatest care was to accept in a seemly and gloomy manner as many glasses of whisky as were offered to them.

His wife's eyes were hollow and glazed from want of sleep; she stood in her Sunday gown and white cap, receiving condolences without a tear, and with the invariable reply, "Sure it couldn't be helped."

She hardly knew whether it were night or day, or how often the evening light in the doorway had turned to blackness, and the blackness quickened to cold blue-grey dawn since they had pulled the feather-bed from under her husband in order that he might, in accordance with ancient custom, breathe his last on the mattress. Her two married daughters dispensed the whisky and the punch at a table near the door; in the bed-room behind the kitchen the more honourable visitors sat with their hats on, and became sapiently and solemnly tipsy. 
The room was set out for company; a brand new counterpane covered the mountainous bed, a naked mahogany table stood in the centre, bearing a black bottle, a loaf of bread, and a two-pound lump of butter on a plate. A dazzling three-and-sixpenny hearthrug was placed on the earthen floor in front of a fire-place without a grate.

"I had not the pleasure of the-the-the dead gentleman's acquaintance," said one of the visitors, a stout and greasy public-house keeper, who had driven over to the entertainment with a mutual friend, from a town twelve miles away. "But I undherstand he was greatly respected in this neighbourhood, and all his family the same."

The eyes of the speaker were of a moist redness befitting the occasion; his voice had a husky roll in it, and the raw and tepid reek of bad whisky accompanied the eulogy.

"As for respect," rejoined the mutual friend, addressing the hearthrug with slow determination, "he had it, the Lord have 
mercy on him, and more than he'd ax of it. Ye needn't be talking of respect."

Several of the party remarked, "that's thrue," and the publican felt that he had said the right thing. Danny Quin's son here rose and went round the circle with the bottle. The attention was accepted with protests, or with groans that betokened indifference to all earthly affairs. Young Quin sat down again. He was not drunk, but he had been drinking and crying on and off for three days and nights, and his big limbs felt tremulous and his brain hot.

"A nice, dacent little man as ever was in the barony," said an old woman glibly; "the Lord have mercy on him, 'tis he got the death very sudden "- she crossed herself- " and very quare, the Lord save us."

"I undherstand," said the publican, conscious of leading the conversation with ability, "that he sustained fatal injuries from a fall."

"Arrah, what fatal injuries!" returned the old woman with scorn; "no, but to 
break his neck was what he done. Didn't he walk out over the brink o' the big sandpit in Cashel the same as one that wouldu't have the sighth, an' he a fine soople man no more than seventy years? "Twas like a reelin' in the head the crayture got."

The tone was that of cautious supposition, and it was casy to discern the desire of contradiction.

" "I'was no reeling," said Tom Quin, suddenly addressing the company in a loud voice. "I know well what was on him, and so do thim that was lookin' at him. 'Twas a start he took, the same as if he seen somethin' followin' him. And I hope in God I'll be dead to-morrow if it isn't thrue what I'm sayin', that if he didn't put his hand to the Park-na-Moddhera to sell it he'd be dhrinkin' his glass in the fair of Letter Kyle this day."

His auditors exclaimed, groaned, and crossed themselves. All present, except the publican, knew every detail connected with Danny Quin's death, but they knew 
even better what was due to the dramatic moments in a story.

There was a stir in the kitchen outside, and Quin's youngest daughter pushed her way into the room; crying and clapping her hands.

"The priest is come--they're closin' the coffin on him-oh, dada, dada!" she wailed, and flung herself half-across the table without an effort at self-control.

The women proffered consolation, and raised her red head from where it lay beside the butter. Swaying and lolling, she was propped against their shoulders, with the light full on her convulsed face, and the whole party crushed forth into the kitchen. There was some delay, while a plate, with a heap of silver upon it, was taken from a table outside the door of the house and handed over to the priest, and many faces peered in a circle round the counting of the money. There was more than eight pounds, subscribed in silver and two half-sovereigns by the visitors to the funeral, as payment 
to the priest for masses for the soul of the deceased. It is an institution known as " the altar," and happily combines a politeness to the dead man and his family, with a keen sense of the return that will be made in kind when it becomes the donor's turn to have a funeral. The sight of the gold was balm to the dazed spirit of the Widow Quin. "Thank God, they showed that much respect for him," she said, as congratulations were passed round. " "Twas a great althar."

A windy sunset of January was set forth that afternoon in cold orange and green behind the bogs near Tully Lake. The new railway line ran across them, away in the north-west, and the rails gleamed along a track that seemed to end against the breast of the evening sky. Coming from the east, the line emerged from a cutting in a wooded hill, where blocks of stone, overturned trucks, and stumps of trees with twisted, agonized roots, littered the yellow sand. The wood ran to the lips of the cutting on either side, and the strong fir-trees on the 
height could look down the tawny slants upon their fallen comrades.

Standing below, the jaws of the ugly cleft let in the winter sunset and the twin glitter of the rails, while above, the fir-trees strove against the evening wind. It was worth remaining still to look at, in spite of the cold, and Mr. Wilfrid Glasgow, with two long account-books under his arm, and the peak of his cap over his eyes, stood for at least a minute surveying alternately his own handiwork and that of his Creator. He felt a proper admiration for both; impartially he perhaps thought that his own was more deserving of credit. At length, turning his back upon the sunset, he walked along the line to where a road crossed it. As he climbed some bars and swung himself down into the road it could be seen that he was active, with the skilled and wary activity of forty. He was tall and slight; when his hat was on, his fair thin moustache and light figure made short-sighted people place him in the early thirties. 
Voices and footsteps were on the road, and groups of people straggled towards him in the twilight. 'They were the remnant of Danny Quin's funeral cortége, and even at a distance of a hundred yards the blatant drawl of drunkenness was discernible in their conversation. He passed quickly through them, and walked fast till he was clear of the reek of whisky, tobacco, and stale turf smoke that followed them.

"What swine they are," he thought, drawing a long breath. He was walking in a bend of the road where trees stood up on either side, and in the shelter the twilight seemed to fall as heavily as dew. A cold, sharp moon came forlornly from behind a wisp of cloud ; the road glistened pallidly in its light, and he saw a tall man walking unsteadily towards him.

"Good-evening, Quin," said Mr. Glasgow, recognizing as he neared him the young man's white face and dark beard; "I was sorry to hear of your trouble. Only four days ago I was talking to your father, and I 
was very much shocked to hear how sudden his death was."

Quin stood still in the middle of the road. with his soft black hat pulled over his brows. He breathed hard, and Glasgow thought he was going to cry. Instead of doing so, however, Quin caught him by the arm.

"How dar' ye bring up me father's name to me?" he said, in a loud voice. "If it wasn't for you and yer railway the stones wouldn't be over his head this night!"

Glasgow shook his hand off.

"Go home, Quin, go home," he said, not unkindly. "I'll talk to you to-morrow."

" What do I want o' yer talk when ye have the bad luck dhrew down on us! God knows ye talked enough to me father, blasht ye !" Quin here unloosed his terrified angry soul by the simple channel of bad language. "I'll have satisfaction out o' ye, ye English hound," he raved on, seeing that Glasgow was turning impassively away. "You that laughed when I axed ye to let me father out o' the bargain! Well I knew that there was 
none of us'd do a day's good afther it__ " he faltered and sobbed.

Glasgow knew enough of the man to take him quietly. He looked at him as he stood in the moonlight with the tears running down his hairy cheeks, and walked away. He had not gone far when the imperative sting of a bicycle bell made him move to one side with the resentment inevitably roused in the pedestrian by that sound. Looking back he saw Lady Susan French skimming past Tom Quin; a wheeled apparition that must have been as startling to him as an Apocalyptic vision. Glasgow had dined at French's Court the night before, and, as he took off his cap, Lady Susan recognized him.

"How-de-do ?" she called out, and jumped off, "I must take things easy and give my husband a chance. He was pounded by that awful hill outside Letter Kyle. Would you lead my bike? Thanks, awfully." 


\section{CHAPTER III}

Torrents of soft grey rain were falling on Fornagh Hill. The furze-bushes were grey with it, the slatey walls gleamed darkly, the streams rushed in yellow fury over the ledges of rock. The new red coat of Dan O'Driscoll the huntsman (familiarly known as Danny-O) had purple patches on it where the wet had soaked through, and, as he himself expressed it to one of his friends, "every step he'd take, the wather was gabblin' in his boots." At the time of this remark, he was on foot in the centre of a crowd of men and boys, who had apparently risen from the hillside to point out the precise spot where the fox had gone to ground.

" "Tis within in the gully he is!" shouted 28 
one of them. "I heard the dogs yowling, and whin I seen him, there wasn't the breadth o' yer nail between himself and the first o' thim."

That which the speaker had referred to as "a gully" was a covered-in drain that carried off the waters of a small stream beneath a road and down the hillside, its lower opening being at this moment blocked by a large yellow cur, whose owner was sedulously pinching its tail as a stimulant to its reluctant advance upon the fox. A small group of riders huddled, with turned-up collars, under the lee of a high furzy fence; their muddy horses steamed, with the wet reins hanging loose on their necks. One lady and four men were all that the rocks and fences of Fornagh had left of the field. The dispensary doctor's chestnut was bleeding from a cut on the fetlock, Mr. James Mahony, a hard-riding farmer, had a dark patch of mud on his shoulder, and Major Bunbury was swearing quietly to himself as he examined an over-reach that had stained 
his mare's white pastern pink with blood. Lady Susan's big bay had lost a fore shoe. Lady Susan's face was an unbecoming, diffused pink; the rain beaded her dark eyebrows and ran down her well-shaped nose; her hunting cravat might as well have been a wet dishclout. Under the circumstances, perhaps, the epithets which she was applying to the weather and the country were excusable.

"What can have become of Hughie?" she said for the twentieth time, bending her head to let the water run out of the brim of her hat; "I don't remember seeing him since that place where the cow ran after us."

"Clinkin' good fencer she was too," said Major Bunbury, "she went two fields with us. Upon my soul, I don't know what happened to Hughie. I'd quite enough to do to look out for myself."

"I hope he's all right," said Lady Susan, easily, " that horse wasn't going very kindly with him."

"Oh, he's all right. Probably he's done 
for the horse, though, in this infernal country -bleedin' to death under a furze-bush somewhere, and no wonder, when they make their fences out of razors and porridge."

"Glasgow goes well," remarked Lady Susan, in a lower voice, eying Mr. Glasgow where he stood talking to a countryman. "I was very glad he was there to give me a lead-you weren't much good to me, Bunny dear!"

"Would it be putting too much delay on your ladyship to send for a tarrier?" said Danny-O, the huntsman, approaching Lady Susan; "there's one Dinny Hegarty that lives back on the hill here, and they say he have a grand dog."

Lady Susan listened in bewilderment to this request.

"Oh, certainly. I don't know what he wants," she continued in her strident soprano, to Mr. Glasgow; "I wish Hugh would come and look after his own hounds, I can't speak Irish."

"I saw Captain French having rather a 
time with that young horse," said Mr. Glasgow suavely, "you ought to have a try at him, Lady Susan; a lady will often make a horse go when a man can't-at least, some ladies can."

Lady Susan cast her dark eyes upon him and laughed.

"Oh, I say, that's what they call blarney over here, isn't it? We call it humbug in England, you know!"

None the less, her opinion of Mr. Glasgow rose, and, so much is there in the manner of saying a stupid thing, he was pleased by the approval and did not notice the stupidity.

The emissary to the home of " the grand dog" was already on his way over the hill, speeded by injunctions from his friends to " kick off the owld shoes and be hirrying." The remainder of the party applied themselves to the agreeable device of damming, at the upper end of the drain, the stream that flowed through it, with the object, as was explained, of "gethering a flood," which 
when released, would wash the fox out before it.

At intervals a rider or two arrived, hot, wet, and full of explanations of the cause of delay, but of the new Master there was no sign. Slaney Morris was one of these later arrivals. She proffered no excuses, being probably aware that these were made for her by her mount with an eloquence beyond all gainsaying. Slaney had, in an unpretentious way, ridden from her youth up, but she rode merely as a means of transit, very much as people use omnibuses; her enthusiasms were reserved for other pursuits. She was now seated on an elderly brown mare, whose natural embonpoint was emphasized by Uncle Charles' humane scruples on the subject of clipping horses. As a further tribute to his clemency, the brown mare's tail had passed undocked through the changing fashions of fifteen years, and hung like a heavy black skirt, in righteous protest against the spruce abbreviations of the French's Court horses. 
Mr. Glasgow looked at Slaney, at her oldfashioned habit, at her saddle, horned like the moon, at the mare's tufted fetlocks and dingy curb-chain, and realized that Miss Morris's most sincere admirers could not attribute to her the sacred quality of smartness. With Mr. Glasgow, as with most of his countrymen, smartness came next to cleanliness and considerably in advance of godliness. He had often ridden with Slaney, and the points he now uncomfortably noted had merely seemed an unimportant part of the background of a life whose charm depended on culture and not on fashion. $\mathrm{He}$ wished that he had not persuaded her to come out.

The rain had turned to a thick mist; the hounds sat on the soaked grass in solemn and disconsolate patience, looking as sapient and as silly as only hounds can; the crowd of country boys remained as indifferent to the weather as if it had been a summer breeze; and after what seemed to the shivering riders a long delay, the emissary re- 
turned, breathless, with the grand dog slinking at his bare heels. The yellow cur was withdrawn by the tail from the lower end of the drain, and the terrier was rammed in like a charge into a gun, its owner, a very respectable elderly man, lying flat on his face in the mud, with his head in the drain, bellowing encouragement. Faint squeaks from the bowels of the earth soon testified that the combat had begun, and the owner redoubled his bawls of "Good boy! good lad!" At this moment a shout arose from the road above that "the flood was loosed," in other words, that the artificers of the dam had lost patience, and had turned the pent-up waters of the stream once more into the drain. Dinny Hegarty arose from the lower end to protest, but he was too late. There was a chorus of shouts, "The dog'll be shoked" - "The two o' thim'll be shoked" - "There isn't as much wather as'd shoke them"- "Faith, the divil himself"d be shoked in it!"

What were the experiences of the sub- 
terranean combatants none could tell; the flood burst from the lower end of the drain and ran down the field brown with mud and redolent of fox, and the pack, without a moment's hesitation, pursued it hotly down the field till, amidst yells of laughter, it escaped from them into a boghole. After a brief interval, muffled hostilities recommenced in the drain; two spades and a pick appeared, as if by magic, and a shaft was sunk upon the squeaks.

"Give over the spades," shouted Danny$\mathrm{O}$, as the roofing stones of "the gully" appeared, "the hands is the besht. Hurry now, before he'll go north in it from ye !"

"Arrah, what north! he haven't room to turn in it!"

"Dom yer sowl, he'd turn in a kayhole!" "Go get a briar!" roared another voice, "he isn't two foot from the hole! Twisht it in his hair now-twisht it, can't ye, and dhraw him out!"

The principle was that adopted by dentists in extracting the nerve from a tooth, 
but the briar failed of its office. The spade and pick were again resorted to, and observations were taken by a small boy.

"The daag have him!"

"Is it by the tail?"

"No, but in a throttlesome way!"

"Come out now," interposed Danny-O, " till I thry could I ketch a howlt of him."

"Put on yer glove, Dan; take care would he bite ye." "Sure, the gloves is no use, only silk." "A fox can't bite through silk. Wrop yer hand in silk and he can't put a tooth through it!" Thus, and much more from the chorus, while Dan, addressing an eye of scornful and civilized humour to Mr. Glasgow, commanded that a "gowlogue" and a bag should be brought to him. The young man who had been leading his horse about leaped into the saddle and undertook the errand, and the little boy who had been entrusted with the doctor's wounded chestnut immediately pursued him at an emulous canter, with his bare feet thrust into the stirrup-leathers. Presently both returned 
at full gallop, one with a forked stick, the other with a meal sack, and then, dazzled by success, proceeded to race round the field. The hounds started once more in pursuit, and were themselves pursued by Danny-O, while the digging party broke into enthusiastic cheers.

Lady Susan was not at all amused. She felt much as a devout clergyman might feel at beholding a low travesty of the Church service, and she was almost shocked at the way in which Major Bunbury and Mr. Glasgow laughed.

"Men will laugh at anything," she said, turning to Slaney, "but $I$ call this awful rot, you know. Hughie gave a lot of money for these hounds, and this sort of nonsense should not be allowed."

"I'm afraid you've got to learn a good many new things about hunting when you come to this part of Ireland, and to forget a good many more!" said Glasgow, looking up at her with his charming smile. It was a smile that Slaney had often thought of 
when she lay awake at night, but in none of her reveries had she ever fancied its light being shed upon Lady Susan.

At about this moment Hugh, three miles away, was engaged in pulling down the stones of a loosely-built wall with the handle of his whip. He was riding a tall, powerful, young grey horse, and was holding him hard on the curb as he leaned over and pushed at the stones. It was obvious that horse and rider were on bad terms. Hugh's face was white, and splashed with mud-mud from the hoofs of the farmers' horses - behind whom he had galloped through dirty lanes; there was a long red scratch on the grey's shoulder that looked as if it had been made by a spur, and Hugh's new velvet cap had obviously been on the ground. The wall was reduced to two feet high before Captain French turned his horse and put him at it. He tried to pull him into a walk, and swore at him as he curveted and sidled, chafing against the curb. The horse refused, whirled round, 
and finally bucked over the wall, lifting his rider perceptibly in the saddle. There was but one fence now between Hugh and the road. It was a large bank with furze bushes growing on it, and a small ditch in front of it. Hugh trotted down its whole length with a sick, angry heart, looking for a low place.

"My God!" he said to himself, "I can't ride at it. It's no good trying."

One spot seemed to him a trifle lower than the rest, and setting his teeth, he put the horse at it. The effort to command himself and not to pull the horse's head as he came to the jump amounted in its way to agony; he did not know if he were glad or sorry when the grey, soured by the day's misadventures, swerved from the fence and bucketed round the field, pulling hard and trying to get his head down. Hugh stopped him and dismounted. He would not think of what he was going to do, but there was a hard knot in his throat as he walked the grey across the field. He tied the lash of 
his whip to the reins, and climbing on to the fence, led him over it. The horse followed him as lightly and quietly as a dog, and stood still to let him untie the lash. His hand shook, and he did it awkwardly, while the lump in his throat grew bigger.

The events of the morning were present with him. The jovial breakfast-table at which he had played so sorry a part; the look of the grey horse bucking as he was led round to the door; the cold, sick feeling when the hounds opened on the fox in covert; the look of Glasgow's back as he and the others disappeared over the hill, leaving him stuck at the first fence, engaged in that half-hearted battle with his horse that had resulted in a fall for them both. He hated them all-Bunbury, Glasgow, the road-riding faction, who had volunteered with horrible sympathy to show him the short cuts: he almost hated his wife for the easy confidence in him that he knew he did not deserve.

"I'll get over it," he said to himself, 
swearing furiously and futilely. "After all, this is pretty nearly the first time I've been on a horse since that smash. Damn you, you brute, keep quiet!" This to the grey, who was fidgeting and pulling, with his ears pricked in expectation of anything and everything. "I've never had a right feel about a horse since that time." He pulled out his flask and took a drink-his wife had given it to him-and as he put it back he thought, with almost the bitterest pang of all, that she would never understand-that he could never tell her.

The note of the horn struck on his ear, and, looking back through the rain, he saw the hounds coming quietly along the road behind him. Lady Susan and Mr. Glasgow were riding in front of them, and he knew that the time had come when he would have to begin to tell lies. 


\section{CHAPTER IV}

Slaney was reading Swinburne's "Atalanta in Calydon." It was Sunday afternoon, and she had dined in the middle of the day. It would soon be time to get ready for afternoon service.

Before beginning to read she had looked for a moment at the name "Wilfrid Glasgow" at the beginning of the book. The same hand that had written the name had marked with heavy and frequent lines the passages most approved by the writer. It is a habit that may be intolerable to succeeding readers, but Slaney did not take offence. Her hazel eyes, that had surveyed Uncle Charles this morning with such impartial severity when he upset his cup of tea, dilated and lingered among the ringing lines; she raised them 43 
and looked out with a quickened pulse at the bright afternoon and the clear rugged outline of the mountain. The drawingroom window commanded a slope of rough lawn, the black and swirling curve of a river, an opening to the west through a young wood of larch and Scotch fir letting in the barren mountain, leaning aslant, and the sunsets that wrought and died upon its shoulder.

"In his heart is a blind desire, In his eyes foreknowledge of death."

The approval of Mr. Glasgow was firmly and neatly given to the passage; she felt it to be the mouthpiece of his soul, and she felt also that hers was probably the only soul within a radius of twenty miles capable of apprehending Mr. Glasgow's in its higher walks. Slaney remembered that at dinner last night Lady Susan had gaily announced that she hated all poetry-" at least all good poetry." The recollection was inconsequent, but it was agreeable.

"Mrs. Quin from Cahirdreen 's outside in 
the back hall, Miss Slaney, and would be thankful to speak to you."

Thus Tierney, the pantry boy; Slaney was irritably aware that two buttons were missing from his jacket. It would need poetry of the highest moral tendency to preserve the serenity of an Irish housekeeper.

Slaney went out into the draughty hall wondering dismally if it would be the cough-bottle or the burn-plaster that would be required, and found the widow Quin awaiting her in tears. Slaney had the turn for doctoring that is above all things adorable to the Irish poor, whose taste for the contraband finds in a female quack a gratification almost comparable to "potheenmaking." She understood them and their ailments by nature and by practice, and, since her childhood, had been accustomed to go to their deathbeds, and their funerals. Such scenes moved her strongly, but she had learned to prize the artistic value of strong emotion. 
The hood of Mrs. Quin's blue cloak was drawn over her face, a fact implying mystery as well as tribulation. Slaney immediately came to the conclusion that her husband's will had not been satisfactory, and addressed herself to the task of arriving at the object of the visit with as little preamble as possible. Nevertheless it was with much circumlocution, and with many apprehensive glances at the closed door, through which was audible Uncle Charles' Scripture lesson to the pantry-boy, that the widow Quin finally delivered her soul.

"But whatever I cried afther Dan," she said, after a lengthy exordium on the virtues of the deceased, "Tom have him cried out an' out, an' indeed 'tis for I knowing the wish you had always for Tom that I came down throubling your honour. Sure yerself knows he was always innocent like, and when he was a child not a word out of him the longest year ever came only talkin' of God and the fairies, and the like o' that, and that was no way for any poor crayture to 
be. Sure yourself knows well the way he was. Ye had undherstanding always, God bless ye-"

"Are you afraid his head is getting wrong again?" interrupted Slaney inexorably. Mrs. Quin fell at once into a raucous and tearful whisper.

"It's whatever owld talk the people have about that place above in Park-na-Moddhera that has him desthroyed. Every spadeful that's throwing out o' that hill it's the same to him as if it was down on his heart they were throwing it, and sure they say that grey fox or whatever it was poor Danny seen is like a witch or a fairy that'd dhraw down bad luck if it wouldn't be let alone, the Lord save us__ she crossed herself; " didn't Danny tell me one time he felt like a wind from the say coming bechuxt his skin and his blood afther he seeing the same fox?"

"But Tom has nothing to say to the hill now," said Slaney; "why should the bad luck come to him any more than to Mr. Glasgow ?" 
"Sure isn't that what I'm tellin' him, but what himself says that it's bechuxt the two o' thim. God help the crayture, ye wouldn't like to be listening to him." Mrs. Quin wiped her eyes and groaned; "maybe your honour would spake a word to him, or maybe"-she turned a crafty eye on Slaney - "ye'd spake a word to Mr. Glashgow, maybe he wouldn't ax to take any more gravel out o' the hill if it was your honour told him the way Tom is."

The opportunity of speaking to $\mathrm{Mr}$. Glasgow did not come as soon as Slaney had expected. He had given her to understand, in the ambiguous special manner with which he chose to beguile her, that he would meet her at afternoon service, and walk home with her; till the second lesson the special manner was ample guarantee, then the ambiguity began to suggest itself to her memory. She walked home with Uncle Charles, and listened for the twentieth time to his reprobation of the Canon's popish practice of turning to the east during the 
Creed. The Honourable Charles Herrick was an elderly and prosperous bachelor, whose blameless life was devoted to two pursuits, gardening and writing controversial letters to the Church papers. $\mathrm{He}$ was a small, dry gentleman, very clean, and not in the least deaf. Strangers always experienced a slight shock on finding that he was not a clergyman.

Slaney put away her best hat, and felt that there were yet many hours till bedtime. Those who lay out with a confident hand the order of a day's events would do well to prepare also an alternative.

Yet Fate had, after all, reserved a blessing.

Slaney had scarcely settled herself by the fire, when she heard Lady Susan's voice in the hall, and following on it the voices of Hugh and Mr. Glasgow. The afternoon leaped again into life and meaning. As she came into the lamp-lit hall to meet her visitors, Lady Susan and Major Bunbury realized in their different ways that she was better-looking than they had believed. Her 
dark hair rose full and soft from her white forehead, in the simplicity that is often extolled, but is seldom becoming ; her complexion was pale and tender with western air and country living, the refinement that was so ineffective at Hurlingham was here pervading and subtle. Lady Susan looked hard at her, and promoted her at once and ungrudgingly from the ranks of non-combatants. Major Bunbury felt that his special sister (who read Carlyle and played Scarlatti) would like to meet her. Although he hunted six days a week, he kept a soul somewhere, and his sister knew where it was.

They all sat down in the firelight of the drawing-room, where the tall west window showed a clear twilight sky, tinged with pink, and barbed with a moon as hard and keen as a scimitar. There was a quaint and sprawling paper on the walls, a band of brass gleamed round the wide opening of the fire-place, a slight smell of turf and wood smoke added its sentiment of country quietness to the air. 
"It was jolly coming over," said Lady Susan, displaying a good deal of drab gaiter as she leaned back and sipped her tea, "but we're not going to have any hunting tomorrow. My bike was breaking ice on all the puddles."

"I thought it was going to break me when you overtook me in the avenue just now," said Mr. Glasgow, in a tone that masked surprisingly well the sentiments he had expressed to Slaney about the modern young woman and her bicycle. He had not thought of mentioning that when the modern young woman possessed a figure that did not admit of a second opinion, and a title, his views might be subject to modification.

"I shan't think of taking the hounds out to-morrow," said Hugh; "Dan knows the country, and he says it would not be the least use."

Inwardly he was telling himself that he was a coward and a cur, because he felt such entire thankfulness for the frost. $\mathrm{He}$ had told them all how the leg that he 
had broken at polo had stopped him last Friday, when the fox had been run to ground on Fornagh Hill, and he hated himself for his own fluency in lying. His horror and despair were out of all proportion to the fact of a broken nerve. $\mathrm{He}$ could do but one thing well, and that one thing was taken from him. He loved his wife with all the strength of a very simple and kindly nature, but some new, chill instinct told him that this was a disaster that it would be wise to hide from her. So far, at all events, his secret was in his own keeping.

For ten full minutes Lady Susan talked of the run, lamented the misconduct of the grey horse, and with an enjoyment of a twice-told tale, that was characteristic of her very moderate mental abilities, regaled Mr. Glasgow with excruciating imitations of Danny-O and his satellites on the occasion of the digging out of the fox. Glasgow, with his eyes fixed on her glowing face, listened delightedly; Slaney, through her 
talk to the others, was conscious of a newfound bitterness.

"I say, Slaney!" Lady Susan called out, "I want you to talk sense to your friend, Danny-O. The old pig refuses to draw that gorse above the railway-you know," turning to Glasgow, "that place where the cutting is; he said it was an unlucky place, and that the fox there was a witch! Such rot!"

Slaney did not answer at once. There are some people for whom the limits of the possible seem to be set farther out than for the rest of the world. They see and hear things inexplicable; for them the darkened glass is less dark, to them all things are possible. It cannot be called superstitionbeing neither ignorant dread nor self-interested faith; it seems like the possession of another sense-imperfect, yet distinct from all others. Slaney had seen and heardbetween the sunset and the dawn-things not easily accounted for; she herself accepted them without fear; but she knew- 
as any one who knows well a half-civilized people must know-how often a superstition is justified of its works.

"I often think," she said slowly, "that it isn't much good to go against the country people in these things."

"I don't agree with you, Miss Morris," struck in Glasgow. "I never give in to them. The other day I told one of my fellows to cut down a thorn bush that came in my way surveying. He told me it was a holy thorn, and he wouldn't stir it. I just took the bill-hook and cut it down myself."

Mr. Glasgow gave his fair moustache a twist, and looked at Lady Susan. He had a noble gift of self-confidence, and a quietness in manifesting it that made him immediately attractive to lesser intelligences.

"Quite right too," said Lady Susan, in her strong clear voice, "that's the way to talk to these people. Why, it's as bad as the Land League, not being allowed to draw one of the nicest coverts in the country, 
for rubbish of that kind. Hughie, if you don't kill that old white fox I shall think you're in a funk too. You Irish people are all the same. I don't care, Mr. Glasgow and I will take the hounds to Cahirdreen, and we'll have that white brush! I want it awfully to show to the people at home, and tell them I got a witch's brush!"

"You could say it was an evolution of the broomstick," said Slaney.

Mr. Glasgow laughed, and it gave Slaney some satisfaction to see that Lady Susan was bewildered.

When the French's Court party betook themselves to their bicycles for the homeward ride Mr. Glasgow came back from the hall door close to Slaney. She had stirred the logs till they blazed strongly, and the warm eager flicker met the unearthly stillness of the moonlight.

"I couldn't get away in time for church," said Glasgow, as if dropping into an undercurrent of both their minds; "I had a terrible amount of work to get through. 
It isn't finished now, but-I just let it remain unfinished." He looked at her, to see in what manner she would show her gratification, and found her eyes cast down, and her sensitive mouth closed in an unsympathetic line. He had never known her other than sympathetic, with that quick brain sympathy that was especially hers; she had shown him without reserve or femininity that his conversation was agreeable to her, but her heart was hidden from him, perhaps from her own inability to reveal it. He felt, as his eyes dwelt on her, that she was complex and unexplored; he was pleasurably aware that she was attractive.

"What have you been doing with yourself?" he went on, in his confident, quiet voice. "I thought you would have come down to the cutting yesterday to see how we are getting on."

"It was too cold," said Slaney, indifferently; " besides, I went to French's Court." "It was rather cold, especially when one 
waited and was disappointed," said Glasgow. "I always looked upon you as a person who kept your promises."

"There is only one thing more irrational than making promises, and that is keeping them," said Slaney, with a flippancy that Glasgow was not accustomed to in her; "but in this case there was no promise."

"When a thing has happened very often, one has a right to expect it to happen again," he said; "that is how one arrives at most conclusions."

"Sometimes things come to a conclusion of themselves," said Slaney, with a little laugh.

She looked up and found his eyes waiting to meet hers. They had an undisguised, irrelevant tenderness, and Slaney was surprised into accepting it for one silent moment, while her heart beat and her head swam. She recovered herself, as one might struggle up out of soft ground. The thought of Lady Susan was like setting her feet again on hard rock. 
"Mrs. Quin was here to-day," she said, catching at the first subject that suggested itself. "From what she tells me, I am afraid that Tom Quin must be going out of his mind."

"I should believe that if I thought he had any mind to go out of," said Glasgow irritably. Slaney was not playing the part he had cast for her, and the subject of the Quins was not calculated to soothe him. "The whole family have persecuted me about that gravel-pit-Quin, and his mother, and the red-haired sister, and all. I wonder if they really think I am going to give up working the place to please them!"

"Yes, I think they do," replied Slaney, staring before her into the blue and pink and yellow flames of the wood fire. Then, after a pause, "I am not quite sure that I don't sympathize with them."

"Sympathize with what?" asked Glasgow impatiently. "With their distress, or with their superstition?"

"Perhaps a little of both." 
At his tone her fastidious upper lip had set itself again into an unsympathetic line; her forehead scemed as white and quiet as the moonlight behind her.

"Very well," said Glasgow, provoked and seornful, yet beyond all things attracted, "I take all consequences. I appropriate all the ill-luck. Now will you sympathize with me?"

"Oh, don't!" she exclaimed, putting out her hand with a horrified gesture, as if what he had said would be instantly overheard.

"Will you ?" he repeated, deliciously perceptive of her fear, and before he realized what he was doing he had kissed the fastidious, spiritual mouth, and found it a trembling and human one.

"You can learn twelve of the 'I wills' of the Psalms for next Sunday, Tierney," said Uncle Charles' voice in the hall, "and three more of the "Plain Reasons against joining the Church of Rome.'"

Uncle Charles opened the drawing-room 
door as he made the concluding charge, and met $\mathrm{Mr}$. Glasgow in the act of taking leave of his niece.

When Slaney went up to her room that night she sat for a long time by the fire, with her elbows on her knees and her face in her hands. There was a little table by her. On it were an old-fashioned desk, a good many books, and, half-emerging from the paper in which it had been wrapped, a number of the Fortnightly Review. She sat for a long time, and sometimes in the silence of the house the beating of her heart was like a voice in her ears, telling her irrepressibly of her own weakness and strength, of depths of herself hitherto unknown. Her pure and ardent nature was awakening out of narrowness, her clear intellect scaled all possibilities like a strong climber.

As if she had yielded to herself for too long, she sat up at length, and after a moment, took up the Fortnightly Review, and began to turn its pages over-Glasgow 
had brought it to her that afternoon-and she searched for the article that he had commended. Cold logic and relentless statistics would inflict composure, would steady her down to the level of sleep.

Two of the pages fell apart where a sheet of paper had been thrust in; she was abruptly confronted by a letter in a large, heavy handwriting. The eye is quicker than the will. Before she snatched her eyes away she had taken in its half-a-dozen lines. For some moments she sat perfectly still, while the blood came with a rush to her cheeks and forehead. Then she crumpled up the letter and threw it into the fire. 


\section{CHAPTER V}

THE frost that had sharpened the moon and armoured the pools, held its ground for but one night. The voice of the south moaned in the casements, a grey, strong rain followed it, and on the morning of the second day a clean wind blew across the soaked fields, and the sun came forth in a sky of new-born blue.

Tom Quin's red-haired sister stood at the door of her house, and looked across the furzy uplands to where a long wood climbed and sank on a spur of Cahirdreen hill. Her hair seemed on fire in the sunshine, and the pupils of her light eyes were contracted to pin points by the glare from the whitewashed lintel.

"He's coming," she said, turning back 62 
into the house, where her mother was sitting on a stool by the fire, with a cup of tea in her hand, and a bare-legged grandchild squatting beside her on the warm hearthstone. Since her bereavement, the widow Quin breakfasted fitfully by half-cupfuls at intervals during the morning, and did not sit at the table.

"Oh, musha, musha, a quare hour o' the day he comes to his breakfast, goin' on eleven o'clock, an' he that wint out before it was makin' day!"

Mrs. Quin shed tears, and little Mikeen utilized the opportunity by burying his dirty face in her cup, and taking a long drink of the bitter strong tea.

Tom Quin did not waste words on his family when he came in. He sat down on the settle, with his hat on, and his eyes fixed on the floor between his muddy boots. His dog, a black-and-grey cur, remotely allied to the collie breed, snuffed with an habituated nose at the pots and pans under the dresser, found no change in them since 
he had licked them the night before, passed the lair of the cat with respectful rigidity, and lay down as if tired, submitting like a Christian and a gentleman to the fondlings of Mikeen.

"Have they the bridge finished yet, in Tully Bog?" asked Maria Quin, as she took the teapot up from its nest in the hot ashes.

Quin raised his heavy eyes quickly.

"Ye think ye're damn wise," he said, "follyin' me, an' axin' me this an' that what was I doin'. Haven't I throuble enough without the likes o' yee annoyin' me!"

"Oh, asthoreen," wailed his mother, "sure it's only that we're that much unaisy for the way ye are, that we'd ax where'd ye go. Take the cup o' tay, asthore, don't be talkin' that way."

Quin relapsed into silence, and Maria was in the act of pouring out his tea, when the long sweet note of a horn struck suddenly on their ears, and Watch sprang 
out of the open door, barking his shrill vulgar bark, and sniffing the breeze. $\mathrm{He}$ was hardly quicker than his master. Before Maria had time to put down the teapot, Quin was outside, listening and staring, and cursing the dog into silence. He saw two red-coated horsemen trotting round the end of the wood, and the note of the horn came again, smooth and melodious. Quin started at a run in the direction of the covert, drawing hard, sobbing breaths as he ran.

On the road at the other side of the covert, Slaney was sitting on Isabella, the elderly brown mare, and wishing that she had stayed at home. To sit on Isabella's back was an experience almost distinct from riding; it suggested more than anything else a school-room sofa propelled into action by a sour and sluggish sense of the inevitable, a school-room sofa that partook of the nature of the governess. Slaney's sharplycut face was pale and sleepless-looking; she was no longer the ethereal creature of the firelight and moonlight, merely an ill- 
turned-out girl, with interesting eyes and a clear skin, who appeared to be absorbed in discussing bronchitis kettles with the dispensary doctor. Lady Susan was a little farther down the road on her husband's grey, the horse who was, so far, the only creature possessed of the knowledge that Hugh was afraid of him. $\mathrm{He}$ was well aware that Lady Susan was not, but that, after all, was a fact that was patent to all beholders.

Mr. Glasgow, turning away from Lady Susan, and looking back as he turned, thought that she was as good a thing to look at as he had ever seen. He was on his way to Slaney, and as he neared her he attuned his eye to that expression of understanding, even of tenderness, that the occasion required. He delighted in the position; it was intricate, it was a little risky, and in spite of Slaney's wrinkled habit and old-fashioned hat, he still recognized the attractive quality in her. $\mathrm{He}$ felt that it was discriminating and chivalrous 
of him to be able to do so, and looking down on her from the mental elevation of his assured horsemanship, and his power of being agreeable to women, he anticipated with sufficient pleasure another harmless deviation or so from the ordinary paths of friendship.

"So you did come out, after all," he began, riding possessively up to her, "in spite of the Witch! Do you know that Dan's afraid to go into the covert, and Major Bunbury's taking the hounds through it!"

The sun shone on the top of his head as he took his hat off; Slaney had not before noticed the exact extent of his baldness. She gave him a conventional smile and nod, and went on talking to Dr. Hallahan. Glasgow waited, lighting a cigarette, and, at the next pause, spoke to her again. His eyes were full of meaning and penetration, and he knew that they were kind, but hers met them with the merest politeness as she answered him. There was a perplexed 
whimper from a hound down at the lower end of the covert; Glasgow caught up his reins and trotted away in the direction in which Lady Susan was already moving. This was not the moment for winding back through the maze of Slaney's mood; he held the clue and could use it at his leisure.

Slaney detached herself from Dr. Hallahan, and rode alone up the mountain road. The hounds had drawn the gorse outside the covert, and were slowly working up through a wood of scrubby aboriginal oak trees, woven together by a tangle of briars; round the outskirts a band of young firs and larches imparted an effect of amenity, but the domain of the oaks had as impracticable an air as the curled and bossed forehead of the mountain bull that was shouting defiance from a neighbouring field. Slaney moved slowly on and up till she reached the top corner of the covert; and pausing there, the brown mare proceeded, with her usual air of infinite leisure, to crop the green spikes of a furze-bush. The 
smoke from Quin's farm rose bluely from the valley below, a long stretch of brown country spangled with lakes lay beyond, and behind all, rising to meet the eye, the sea stood high like a silver wall against the horizon. Curlew were crying on the sunny slopes above Slaney, and the whistling of green plover filled the air. No one was in sight save a rider posted out on the hill to watch the top of the covert; the inevitable mob of country boys was at the lower end, and the sound of Hugh's and Major Bunbury's voices, holloaing to the hounds, came distantly from the bottom of the wood.

Slaney sat quite still, while the life and freshness of the morning passed by her, and left her dull as stone. The thud of a footstep that ran, and laboured in running, did not make her look round; she thought it was the usual country boy till she saw Tom Quin come lurching and stumbling round the far corner of the wood, with his dog panting at his heels. Even at a distance of a hundred yards or more an extravagance 
as of despair was unmistakable about him. As Slaney looked at him, a hound, not far off in the covert, gave two or three contralto notes in succession, and at the same moment there was a rustle in the bracken, a few yards in front of her. A grey face parted the brown fern and looked out at her; a fox's face, with its oblique crafty eyes and sharp refined muzzle, but the fur was silver-grey.

"A thing like an Arctic fox," Slaney heard Lady Susan's voice declaiming on the ice at Hurlingham.

The fox slipped down off the fence through the bracken, crossed the road with a dainty whisk of its grey brush, glided up the opposite bank like a shadow, and was gone. A cold and prickling sensation passed over Slaney, that feeling of "a wind from the say coming bechuxt the skin an' the blood" that old Dan Quin had felt. It died away, and left her with a bounding heart and a reddened cheek, and a sense of intense participation in the events of the moment, 
instead of the lifeless passivity of fivo minutes before. Her courage repelled the shock to her instinct, but her understanding had taken a "list" to the unknown and the impossible, and in spite of the morning sunshine and the candid blue sky, she could not altogether right herself.

A long shout of "gone away" came from the watcher on the hill, and the hounds came tumbling out of the wood in the lovely headlong rush that has the shape of a wave and a thousandfold its impetuosity. With the indescribable chorus of yells and squeals that is known as full cry, they swept past Slaney, and it was at this juncture that Isabella, the brown mare, found herself the victim of a gush of enthusiasm. It may have been a survival in her old soul of the days when she had, according to tradition, carried the huntsman of the county pack; it may have been that she, like her rider, was lifted out of herself by the discerning of spiritual things; at any rate, when she found her head pointed 
at a promising place in the fence, she bundled over it with an agility for which no one would have given her credit, and Slaney found herself galloping alone behind the racing pack.

The fox had done all that was most unexpected, had gone away into the teeth of the wind, in a direction wide of any known destination, and the field, both horse and foot, were all left at the wrong side of the big irregular covert. Yet Slaney had not gone a hundred yards when Lady Susan and Glasgow were behind her like a storm, and shot past with their horses pulling in the wildness of a first burst. The next fence was a towering bank, wet and rotten and blind with briars, feasible only at a spot where a breach made for cattle had been built up with loose stones. Glasgow came first at it, checking his young horse's ingenuous desire to buck, and sitting down for a big fly. He was suddenly confronted by Tom Quin at the far side, brandishing a stone as big as a turnip as if in the act to 
throw it, and the young horse swung round with a jerk that perceptibly tried his rider's seat. Lady Susan was close in his tracks, and, far from trying to stop her horse, she gave him a vigorous blow with her huntingcrop, and drove him full pace at the fence and its defender. The grey horse jumped like a deer, and Quin perforce sprang aside, cursing vilely and threatening Lady Susan with the stone. She was gone in an instant, and, before Glasgow had pulled his horse together, Slaney and Isabella were charging the place, Slaney with a white face and a crooked hat, Isabella with her long nose poked well forward to take her distance. With an economical yet sufficient hoist of her hind quarters the old mare was over, while Tom Quin remained staring as if stupefied by the feat.

"Go away, Tom!" called Slaney, as she passed him. "Don't mind them-it's no use-go home!"

She seemed to herself to be calling out of a dream; yet she had never felt so 
strongly and defiantly alive. The thud of galloping hoofs was in her ears, and she looked back in time to see Glasgow's horse clear the stones with a long bound, and receive a blow across the nose from Tom Quin's stick as he landed. Drag as she might she could not calm Isabella, who was bucketing through the heather tussocks with school-girl ardour; when she looked again, Quin was holding his hand to his face, as if he had been struck upon it, and was raving in that inarticulate futility of rage that is not good to see. Glasgow came on like a thunderbolt, and was beside Slaney in a moment, his horse still rampant from the blow.

"He's mad!" she called out through the wind that sang in her teeth. "He didn't know what he was doing."

"Didn't he, though!" Glasgow shouted back, his eyes tracking the hounds where they were flitting like white birds across a green field near the brow of the hill; "he knows now, I think!" 
Lady Susan was a hundred yards ahead. Glasgow let his horse go, reducing the distance at every stride, and leaving Slaney behind. He did not seem like the lover who had found out the secret of her lips two evenings ago.

Other riders were close to her now, converging from different points; she was dimly aware of Major Bunbury below her on the left, riding hard and steady to pick up a bad start; she saw Danny's red coat far away in the heather; she vaguely missed Hugh's. She was in the green field at last, with the hounds casting themselves at the farther side of an ugly stone-faced bank plumed with furze-bushes. The grey had refused, with the nervousness of youth and inexperience, and Glasgow was looking about for a better place to get over. At the same moment Slaney saw Hugh galloping towards them up a hillside track on the bay that his wife had ridden the Friday before, and through the maddening din of the hounds opening again on the line, she 
heard Lady Susan call to him to give them a lead.

"There, Hughie!" she cried, "between the two furze-bushes is the only chance. That horse will do it flying."

Hugh cantered to the place, the bay horse pulling and fuming; he looked at the steep face of the bank, the deep ditch in front of it, and knew that to save his soul he could not ride at it.

"It's not good enough," he called out, turning his horse. "We must try round some other way."

. "Try round!" ejaculated Lady Susan, rushing the grey at the fence. "Look at the hounds running like the devil over the top of the hill! Come up, horse !"

The grey horse recognized the inevitable; he came up on to the top of the bank with an effort, and jumped boldly out across the boggy stream on the far side. Glasgow came next, getting over with a scramble, and after him followed the wholly incredible Isabella. As Major Bunbury, cramming his 
screwy mare at the same place, saw Isabella's crafty hind legs fetch securely up on the bank, he said to himself, with some excitement, that Miss Morris was a clinking good girl, and that there was nothing in creation like an Irish mare, young or old. At this juncture his own mare alighted on her chest and nose, and the eulogy was interrupted.

Slaney was but chaotically conscious of subsequent events. The hounds crested the hill, and sped down into the brown and green patchwork of the rough country at the other side, and in a dream-like rush she pursued the flying figures of Glasgow and Lady Susan, scuffling and sliding down rocky hillsides, straining up again with fingers twisted in Isabella's abundant mane, scrambling over rotten fences, splashing and labouring through bog, bucking over loose walls, while physical effort and the excitement of success were mixed up with the fragrance of the beaten sod, the peaty whiff of the broken bog fence, and the conscious- 
ness of encomium and advice from Major Bunbury. There was a check or two, when she was aware of puffing horses snatching their wind, and flushed riders, telling each other that it was a great run, and then again the brown country flowing past her, and the unfailing guile of Isabella.

It was an hour and a half before Glasgow, dropping down into a road from the top of a heathery bank, found the hounds at fault on the edge of a wide and famished expanse, half marsh, half bog. They seemed beaten and spiritless; some were already sitting idle and panting on their haunches, and one of the younger ones was baying at a little bare-legged girl, who was uttering lamentable cries at finding herself in the middle of the pack. She and the few starveling cattle she was tending were the only living creatures in sight. It was a flat and inexplicable conclusion, but it was final beyond all ingenuity of casting.

It was a twelve-mile ride home for Slaney. She turned Isabella's head almost immedi- 
ately, and started at a walk, while the heat and enthusiasm died slowly away, and tomorrow lay as fiat and cold before her as the marsh at her side. She was soon out of sight and hearing of the group on the road, and passed on through the loneliness of the barren hills, a tired figure on a tired horse, forgotten by all. So it was that she saw herself, with that acute perception of the gloom of the position that is with some natures the preliminary to tears.

"What happened to Slaney Morris?" said Lady Susan to Glasgow, an hour later, as she rode home with him. "She vanished like the fox. Is she a witch, too? I think she must be to have got that old crock along as she did."

"Major Bunbury will tell you all about her," replied Glasgow, not without interest in the manner in which the information would be received. "I saw him catch her up before she had gone half-a-mile."

"Oh, the wily and dissolute old Bunny," exclaimed Lady Susan, in high amusement. 
"Won't he hear about it from me! I'm simply screaming for a cigarette," she went on, "and Hughie has my case in his pocket, and he's miles behind-oh, thanks!" She took one from Glasgow's case, and lit it in the fresh breeze with practised ease.

"I suppose Hughie's leg must have been bad again to-day," she said, rather awkwardly, as they moved on again. Glasgow stroked his moustache and looked the other way, with a tact sufficiently ostentatious to impress Lady Susan.

"I saw him come out of the covert over a two-foot wall," Hugh's wife went on, "and he had no more cling than a toy." She paused again, and Glasgow still was silent. "You saw him at that fence where I asked him for a lead," she said, with some genuine hesitation. "What do you think was wrong with him?"

"I don't suppose you can imagine what it feels like to lose your nerve, Lady Susan," said Glasgow slowly. 


\section{$\begin{array}{lll}\text { THE SILVER FOX } & 81\end{array}$}

She took her cigarette out of her mouth. "I've been horribly afraid it was that," she said, in a low voice, and their eyes met in a fellowship in which Hugh could never have a part. 


\section{CHAP'TER VI}

TAKEN from an architectural point of view there was nothing to be said for French's Court. It belonged to the race of stone boxes, with tightly-fitting lids, that were built in Ireland a hundred years ago, the greater box or the less, according to the circumstances of the builder, and it was of as Presbyterian a gauntness as its tribe. Contrary, however, to the rule which ordained that the stone box should, as far as possible, face north and east, French's Court, with its ranks of high windows, looked out into the sunset across a great plain of western ocean. From the edge of the long bare terrace in front of the house, the grass-lands sloped suavely between plantations to the sea, where Atlantic rollers 
charged and volleyed in stubborn fastnesses of cliff. The low hills behind the house were clothed with woods, brown and grey now in the mute suspense of January, touched here and there with orange where last year's beech leaves clung like a stain of rust.

It was a big outlook, and the owner of French's Court was a very small incident of the foreground, as he stood on the terrace and watched the fishing-boats creeping out in the raw, grey calm to the solitudes beyond the horizon. A portmanteau and a gun-case stood on the steps of the hall door, and a brown retriever was moving nervously round the gun-case, hurrying from it now and again to thrust her curly head into Hugh's hand, and beseech him with her amber eyes not to leave her behind. Every dog believed in Hugh, and told him so by the varied and untiring dog methods, but now, with that restless and aching reference of all things to one subject, Hugh gave his hand to the innocent homage 
with the feeling that every one except his dog had found him out. His wife knew it, Bunbury knew it, he writhed under their tact when they avoided all discussion of his part in the run that the Silver Fox had given them; he detected with agony the consideration that prompted Lady Susan's gallant efforts to talk on subjects unconnected with horses. He could have found it in his heart to swear at her and tell her she need not take so much trouble; he would have liked to quarrel with Bunbury and show him which was the pluckier man; he dwelt on the thought with pitiful, childish intensity, and drove his heel into the gravel, half knowing himself to be pitiful and childish.

There are junctures in a life when deficiency of intellect may disastrously alter the moral balance, and the smaller mind may have need of supreme and heroic effort to attain the philosophy or even the sanity that are easy to stronger intelligences. All Hugh's native good-feeling was not enough 
to avail him when he remembered his wife's figure up against the sky on the top of the stone-faced bank, while he turned and made for the byways and highways that had been his portion throughout the day. Passionate admiration, turning to passionate jealousy of her flawless courage, and self-contempt, and knowledge that his eyes would never again meet hers without consciousness of failure; all these because a good little average man had but two ideas in his life, and when one was taken from him, the other sickened like a poisoned thing.

The slow beat of a horse's hoofs became audible on the avenue, and a sombre vehicle, that was half brougham and half cab, emerged from the trees into the open. Its coachman had a long red beard, a frieze coat, and a hat with a silver cord round it; the horse was white and shaggy, the wheels of the brougham turned in as if it were bandy-legged. Hugh recognized the equipage of his Uncle Charles, and stationed himself at the hall door to receive it. 
"It's awfully good of you to come, Slaney," he said, with an effort at his wonted geniality. "Such short notice too. I didn't know that I was going to this shoot till I got in from hunting the day before yesterday."

$\mathrm{He}$ could remember, as he spoke, the mountain stream by which, when riding home, he had made up his mind to go, while the steady patter of the hounds' paws sounded behind him on the wet road, and the honest hound faces that he was beginning to hate looked up at him from time to time.

Slaney and he found the drawing-room empty of all but a smell of cigarettes, and pursuing a fresh trail of it to the smokingroom, found Lady Susan sitting with a cigarette in her shapely mouth, and in front of her a mandoline, from which she was plucking a shrill and agueish chatter of melody, representing a waltz. A grey poodle lay at her feet, with his moustached muzzle buried in the fur rug, and his eyes rolling purgatorially upward in the for- 
bidden longing to lift up his voice and howl an accompaniment to the tune. Major Bunbury was reading a newspaper with that air of serving his country that belongs to men when they read papers. No woman can hope to read the Times as though it were a profession; it is a masculine gift, akin to that of dining.

"Oh, it's only Slaney!" exclaimed Lady Susan. "We bolted in here when we saw the white horse. We thought it was the parson. Well, you're very good to come, dear, and it's very nice to have you." She kissed Slaney briskly on both cheeks, conveying a mingled flavour of smart clothes, tobacco, and careless friendliness. "Hughie could never have gone away and left Bunny and me here together for a week, you know! It would have been hideously improper, wouldn't it? Uncle Charles would have had three fits on the spot, wouldn't he?" She stationed herself on the arm of Major Bunbury's chair, and put her elbow on his shoulder. 
Slaney realized that of the whole party she alone felt the proceeding to be unusual, yet Major Bunbury did not seem to appreciate it.

"Well, I'm off, anyhow," said Hugh. "Make them look after you, Slaney. If Glasgow wants to know anything more about the next meet or stopping the earths, or anything, Bunbury, Dan can tell him." In spite of himself, his voice stiffened till all the good-fellowship was gone from it. "Well, good-bye, everybody."

$\mathrm{He}$ wondered whether his wife would come out to see him off, but he could not ask her. She got up and came to the door, and stood leaning against it as he passed out. She was not quite sufficiently feminine to discern that, in spite of his unprepossessing manner, and bald brevity of farewell, he hated going away from her, and he went down the passage unaccompanied except by his dog.

"I think Hughie's got influenza, or liver, 


\section{THE SILVER FOX $\quad 89$}

or something," remarked Lady Susan, returning to the mandoline, "he's awfully grumpy."

Bunbury got up without answering, and followed his host to the hall door. 


\section{CHAPTER VII}

Mr. GlasGow made no difficulty about hunting the hounds during Hugh's absence. The office was very much to his taste, and its obligations fitted in satisfactorily with his inclinations. These he summarized with a fine brevity. He promised himself that he would wipe French's eye; his exact motive for doing so he did not attempt to define. He calculated that he would have four days of office before Hugh returned. Four days only! The inequality of things! he thought, with an impatient sigh, gathering up a bundle of highly unsatisfactory letters, that he had received that morning, and slamming the lid of his desk down on them.

Fortune favoured him. The weather was 
perfect, from a hunting point of view, there never was better scent, and the foxes ran the way they were wanted. "Bedad," said Danny-O, "if I had a red herrin' in a halther I couldn't make a nater line than thimselves." There were long jogs to the meets through the pleasant soft weather, when Lady Susan rode at the head of her husband's hounds with the acting master, while Slaney and Bunbury followed old Danny at their heels. Once or twice they left off twelve or fourteen miles from home, and a friendship can progress marvellously in the slow return in the twilight, with the golden link of a day's enjoyment, and the easy snatches of talk and silence of a tête-àtête on horseback.

It had become a custom that Glasgow should dine at French's Court on hunting days, and it was on the third of these occasions that a letter from Hugh arrived, saying that he was prolonging his visit for a few more days. The post had been brought in while dessert was in progress. Lady 
Susan leaned back in her chair with folded arms. They were white arms, and had that composure about them that belongs to arms accustomed from their infancy to emerge from the latest variety of sleeve.

"Hughie says that we're bound to go to this show to-night, and he's thanking his stars he's out of it, the little beast!" she remarked presently. "What sort of thing will they do, Slaney? You know all about 'em, I suppose. I never went to a parochial hall in my life. Will they sing the Doxology? I never can remember exactly what the Doxology is. Oh, I say, Bunny, shall you ever forget that night we dined with old Lady Pemberton, when she wanted her pet Bishop to say grace, and she leaned over and told him in her awful solemn old way to say 'God save the Queen'!" Lady Susan laughed her loud short laugh, and looked across the round table at Major Bunbury.

Glasgow, sitting beside her, caught at that passing flash of her glance that was 
intended for him specially, and replied to it with an intimacy that startled Slaney. His face was pale, and had the tired look that comes with mental rather than physical fatigue, but the crisp tingle of the champagne had given its inimitable fillip; the excellence of the dinner had brought him into charity with all men-even with his Irish workmen-and the warm luxury and charm of the surroundings had the effect of a perfume whose dizzy fragrance can steep mind and body in repose. The anxieties that he had to bear alone, the reverses that hit him harder than he dared admit, slept in this atmosphere of ease. "Lovely Thais" sat beside him, and the gods had considerately prolonged the absence of her husband. Even Slaney, who might at one time have complicated the situation, now fell into her place in the general sentiment of repose, and made a pleasant background of literary intelligence and perceptiveness. $\mathrm{He}$ remembered only as a transient caprice the moment, unforgetable for her, that had 
given her life its first touch of passion. He finished his glass of burgundy, and took a cigarette from the silver box that his hostess pushed towards him.

"We'll play bézique in the 'bus," pursued Lady Susan; "we couldn't possibly talk for six miles. I should go to sleep."

"Oh, heavens, not more cards!" groaned Bunbury. "Do you know, Miss Morris, that she made me play rubicon bézique with her for three hours on end this afternoon. I'd hardly got my boots off when she sent William to hurry me down. I wish she'd teach William to play with her."

"I used to play 'Spoilt Five' with the yard boys when I was a child," said Slaney. "I never aspired to any one as grand as William. We used to play secretly in an old loose box, and the cards were so black that we only knew them by private marks on their backs."

Her eyes were clear and half shy, like a boy's. Bunbury looked at her delicate, clever hand, and tried to imagine it holding 
the grimy cards, and wondered how it was that so many impossible things were possible in Ireland.

The concert in the Parochial Hall at Letter Kyle was neither more nor less than such entertainments are wont to be. Lady Susan, in her gorgeous sortie-de-bal, sat in the front row and carried on a conversation with Mr. Glasgow that, thanks to the vigour of her lungs, was quite unhampered by the efforts of the performers, and was only interrupted when some achievement of Letter Kyle millinery stupefied her into a moment of silence. Slaney was inured to parochial concerts. It was beside her that Glasgow had sat at the last of them, not so many months ago. She remembered how angry Uncle Charles had been because they laughed when the school-master's wife had tranquilly omitted the top note in "The Lost Chord" as being beyond her compass. To-night she felt as though a wall had been built between her and the founts of laughter. 
Weighted by encores, the dismal programme wore on, and it was eleven o'clock before the French's Court party could escape from the long incarceration in hot air, winnowed by draughts that were heavy with hair oil. Slaney leaned back in the corner of the 'bus, and the darkness of the heart that she had been striving with fell upon her like a tangible thing. In spite of hot-water tins and a vast fur rug the cold breath of a foggy night made itself felt. The faces of the four occupants of the 'bus glimmered white as the glimmer of the windows. Glasgow was sitting beside Slaney, and some feeling blended of compunction and of desire to retain a captive, made him try to involve her in the desultory talk. She tasted a certain joyless gratification in ignoring him. The road was very dark as they drove through a wood, and the glimmer of Slaney's face was almost lost when Glasgow, determined to remind her of the kiss that had so lightly come and gone between the firelight and the moonlight, slid 
his hand along the rug, and took hers with confident tenderness. It was gone from him in a moment, and Slaney, with that level politeness of voice that is the distilled essence of a perfected anger, was telling Lady Susan that her head ached, and that she would like to sit by the door.

Lady Susan changed places with her, and presently fell to arranging, with Mr. Glasgow, the details of an expedition up the new railway line in a cattle-truck. Their voices sank gradually to that level that indicates to an outside world that it is superfluous. What they said seemed to be wholly trivial, and flagrant only in aridness; yet the low voices, half-lost in the noise of the wheels, had a quality that drove Bunbury and Slaney into a conversation lame with consciousness of what it tried to ignore.

Glasgorv's dog-cart was waiting for him at French's Court, and it waited long before the supper was over, at which Lady Susan made amends for her philanthropy in cigarettes and hock and seltzer. When 
the door at length opened to let the guest out into the fog, Lady Susan was near it, tall and resplendent, with the fur of her glistening silk wrap clinging round her white neck. The door closed, and as she turned away she saw something white under its flap.

"I say, it's a letter," she exclaimed, stooping for it, "some one must have dropped it, and it caught under the door. Why, it's for Hughie-looks like a washerwoman's bill. Funny way of sending it in, isn't it?" she yawned hugely; "well, it will keep, anyhow. Let's go to bed; good-night, my dears." She flung the letter on a table and rustled up-stairs.

Slaney was in the habit of saying her prayers. She knelt down and put her head into the soft cushion of the chair, conscious of little except that she had flung down the burden of another day. She remained for a long time on her knees, with a blank, spent mind, soothed in some dull way by the suggestions of her attitude, till a slight 
sound on the terrace, under her open window, made her lift her head and listen.

The sound came and went, and Slaney was roused to put aside the curtains and look down. There was nothing to be seen but the fog that had risen out of the sea and settled on the land, with frost and moonlight blended in its whiteness; all the world seemed arrested and tranced, all the air charged with its cold and mysterious li] esence.

"It was a rabbit," she said to herself, and instantly, as if to contradict her, a blackand-grey collie passed quickly under the window, with its nose down as if running a trail. 


\section{CHAPTER VIII}

The ring of the trowel travelled far on the wind across the heather, a voice of civilization, saying pertinent, unhesitating things to a country where all was loose, and limitless, and inexact. Up here, by the shores of Lough Turc, people had, from all ages, told the time by the sun, and half-an-hour either way made no difference to any one; now-most wondrous of all impossibilities - the winter sunrise was daily heralded by the steely shriek of an engine whirling truckloads of men to their work across the dark and dumb bog-lands. The trout in the lakes no longer glided to safety at the recurrence of the strange tremor and clatter that accompanied the twilights, the wild 
duck no longer splashed into wing along the water's surface, and the people scattered among the hillsides already counted as their chiefest landmark the red gable of the new railway-station.

Every morning saw a villageful of men shot into it; bricklayers working high up in the gable, stone-cutters dressing limestone blocks with infinite chip and clink, workmen shovelling gravel, and over all the voice of the ganger arising at intervals in earnest, profuse profanity. The Dublin artisans worked in silence, except when one or other trolled forth one of the ditties of his class-genteel romance, with a waltz refrain, or obscure vulgarity of the threepenny music-hall, yet representing to the singer the songs of Zion in a strange land; while the local gang used every chance of proximity to carry on a low growl of conversation. Whether it was the party of twenty whose picks and spades were gradually levelling and filling the unfinished platform, or the two whose voices 
ascended in Irish from the depths of the well that they were sinking, the general topic was the same, and was one that intimately concerned Mr. Glasgow.

"Jim Mulloy's brother told me he seen the paymasther 'ere yestherday in Letther Kyle," said a withered little man, who was mixing mortar with extraordinary deliberation. "He was comin' out o' the bank, an' he havin' the brown bag with him."

"Maybe it's little chance oursel' has of it, whether or no," responded his satellite, a red-faced youth, whose occupation of eternally shaking sand through a sieve might well foster pessimism. "Don't ye know well thim isn't workin' for nothin' "indicating the bricklayers on the gable, and the portly and prosperous stonemasons, chipping away in professional silence. "Short thim fellows 'd be leggin' it away to Dublin if they wasn't gettin' their pay; an' d-d well Glasgow knows it's the likes of us must be waitin' on him !" 
The man who was supplying the sand tilted his barrow up on end and leaned on the handles, secure in the knowledge that the ganger was engaged at the other side of the station in raining down expletives upon the heads of the sinkers of the well.

"It's what they're sayin' beyond," he remarked, jerking his head in the direction of the men working at the platform, "that what has him desthroyed is the bog of Tully. Eight months now they're sthrivin' to fill that spot."

"An' if they were eight months more," said the man who was mixing the mortar, "they'll not fill it." He took off the tin lid of his pipe and stirred up its embers with a horny fore-finger. "Betther for him not to be intherfarin' with the likes o' that place."

The pessimist with the sieve laughed with the superiority of youth, and of a reader of the Daily Independent.

"'There's wather runnin' undher the ground there in every place," went on the 
same speaker, "me father knew that wellsure the bog itsel' is only sittin' on it. There's holes up in Cahirdreen that's sixty feet deep, and wather runnin' in the bottom $o$ ' them. 'Tis out undher Tully that wather goes. Sure there was a man had a grand heifer-God knows ye'd sooner be lookin' at her than atin' yer dinner-she fell down in one o' them holes, and went away undher the ground with the wather. As sure as I'm alive, they heard her screeching up through the bog!"

The reader of the Independent was half-staggered, and the ganger, who had advanced upon the party with the quietness of a dangerous bull, here broke upon the conversation in gross and fervid oratory.

"They're gettin' it in style down there," said one of the platform party. "By damn, if he comes to talkin' to me, I'll throw down the shovel and ax him where is me three weeks' wages!"

"Maybe ye will, Mortheen," rejoined his nexc-cioor neighbour, "an' maybe this time 
next week ye'll be afther him axing him to take ye back."

"Is it him?" replied the undaunted Mortheen ; "little I'd think of breaking his snout for him, or Glasgow's ayther!"

As he spoke, the whistle of an engine, thinned by distance, made itself heard, and away on the horizon the steam cloud blossomed like a silver flower against the sunny sky.

When the engine and its accompanying brake-van drew up at the station, Glasgow's eye could discover no flaw in the exemplary and dead silent industry that prevailed. The shovelfuls flung by Mortheen were heavier and more frequent than those of his fellows, and even the spectacle of Lady Susan emerging in sables from the van and passing among the buckets and heaps of lime, did not seem to be noticed by so much as the lift of an eyelid. It was almost one o'clock, and the ganger, transformed into an official of submissive urbanity, sounded his whistle for the dinner- 
hour. The clatter of tools died out in the space of two seconds, and the men, swinging themselves into their coats, straggled out into the road, slouching, rolling, hitching, and apparently untouched by the desire of the ordinary human heart to keep step.

Their employer's picnic-party was already established in the newly-roofed kitchen of the new station, by a fire of chips and bits of plank. A luncheon-basket stood on a carpenter's bench, a champagne-bottle on the window-sill, and Lady Susan and Slaney were sitting on boxes by the fire, eating game pie. Lady Susan had violets in her toque, and possessed more strikingly than usual that air of being very handsome that is not always given to handsome people. Behind her the empty window framed a gaunt mountain peak, a lake that frittered a myriad sparkles from its wealth of restless silver, and the grey and faint purple of the naked wood beyond it. It seemed too great a background for her 
powdered cheek and her upward glances at her host.

"How far do you want us to walk?" she said, looking over her shoulder at the view, "all the way to that wood there? How silly of you to say the bikes would be no use!"

"I don't dispute the fact that they would have been of use to you and Major Bunbury," replied her host, cutting the wires of the second bottle of champagne.

"It's so contemptible of you not to learn the bike," she went on, with a manner half discontented, half brusque. "It's all prejudice."

"I'm beginning to cultivate prejudice," said Glasgow, retaining the cork with skill, " it's so respectable. Churchwardens and generals and heads of departments are always prejudiced."

"I didn't know that you were so wonderfully addicted to respectability," said Lady Susan, with a laugh and a look that made Slaney feel rather hot-" since when, may 
I ask?" Lady Susan was too careless and too little disposed for the toils of finesse to foster a flirtation for its own sake; when she did find a sufficing motive, these same qualities created a.startling directness of method.

"Since when?" repeated Glasgow. "Oh, since I took to church-going, I suppose. Perhaps Miss Morris could tell you!"

Slaney had become accustomed to these morsels flung to the memory of a past, but they never failed to remind her of the moment when she had placed herself for ever at a disadvantage.

"I'm not a very good authority," she said, with a smile as cold as the January wind ; "Uncle Charles has a better memory for things connected with church-going."

The intention to be unresponsive often makes itself felt more disagreeably than a repartee. It annoyed Glasgow, even while he set it down as an indirect tribute to his desertion. .

"I refuse to be described as a thing 
connected with church-going," he said, looking straight at her and laughing; "I thought I had other associations."

Major Bunbury looked up quickly, not at Glasgow, but at Slaney. Her flushed silence was obvious enough for any one, except Lady Susan, who merely supposed that champagne at luncheon was having its almost inevitable result on the complexion. Perhaps it was by contrast that Glasgow's habitual pallor seemed pastiness, and his easy manner something that struck Major Bunbury as being like bad form.

"I say," remarked Lady Susan, "when are we to go on and see this wonderful waterfall, or whatever it is? Where are the cigarettes? Let's light up before we start."

"I think you'd better not," said Glasgow, "the men will be back directly."

"Well, what do they matter?"

"I think you'd better not," he repeated, in that intimate tone that seemed so uncalled for. 
Lady Susan put up her eyebrows with an expression of petulant inquiry, and something as near a pout as was possible for a person not versed in the habit, but she shut her cigarette-case. Major Bunbury thought he had never seen her look so foolish.

"Is she going to lose her head about him?" was the question that was suddenly driven in upon him. Until to-day, he thought she was merely occupying idleness and exhibiting indifferent taste.

$\mathrm{He}$ and Slaney walked behind her and Glasgow along the muddy road, in that double tête-a-tête now become inevitable; the wind blew cold and sweet off the lake and off the bog-cold, and sweet, and inimitably Irish, like Slaney herself, as M:ijor Bunbury was at this moment capable of expressing it, if he had known that he was making the comparison. His mind had unconsciously stored up many such impressions of her, to what end it had not occurred to him to inquire. The road crossed a trout-stream, and by the bridge 
Glasgow and Lady Susan turned off and began to follow the bank of the little river through a stunted and intricate wood. In the track by which they made their way it was not possible to walk side by side; Bunbury went first, sometimes holding back a branch, sometimes giving her his hand when the rocks of the river brink thrust their slippery shoulders across the way. They spoke little, and by the gift of imaginative sympathy that was hers for those who interested her, she knew that his silence was vexed with misgiving about Lady Susan.

The river was brimming full, and, as it raced, the black water and the cold froth washed in deep eddies between the rocks; the sunlit bank opposite was red with withered bracken and sedge ; the soft booming of a waterfall came to the ear. Passing round the curve they saw the thick and creamy column of water plunge from its edge of low crag to its ruin among the boulders; above it two or three battered fir- 
trees stood on the high ground, grey and straight and rigid beside the lavish rush and confusion.

Lady Susan was leaning against one of the fir-trees, smoking her cigarette, and looking fixedly and dreamily at the water; Glasgow, with her fur-lined coat on his arm, was standing very close to her, looking as if he had said something to which she had not as yet replied. She did not move when Slaney and Bunbury joined them, and was unaffectedly uninterested in general conversation. Slaney had never thought her so handsome; her eyes seemed to look out of her heart and into a remote place unseen of others, instead of summing up things around her with her wonted practical glance.

It was against all theories of woman-kind, yet the fact remained that Slaney liked Lady Susan. 


\section{CHAPTER IX}

The party returned to the station by dillerent ways, that chosen by Slaney and Bunbury involving a good deal of wandering by dark and intricate paths in the hollow of the wood before the high road again was reached. The other half of the picnic was not in sight; and when Slaney and her companion arrived at the station, the engine and brake van, in which they had come, had disappeared, and in their place was another engine that had come up the line with a train of trucks. It was a small and very dirty engine, the driver's white jumper was as grimy as his face, and coal-dust and oil had gone hand-in-hand to effect a general and thorough defilement.

The ganger explained the position respect- 
fully. Mr. Glasgow had found that he was obliged to catch the mail train for Dublin, and he and the lady had started a quarter of an hour before; he had ordered the ballast-engine to wait for Major Bunbury.

Slaney recovered herself on the verge of looking aghast. Major Bunbury kept his eyes away from the neighbourhood of hers, and with almost excessive carelessness made inquiries as to the hour at which the mail train was due at Letter Kyle. It appeared that there remained forty-five minutes before it arrived there, and that the usual time required by the ballast-engine for the distance was an hour and a quarter. Possibilities spread and soaked coldly through Slaney's mind, like suddenly spilt water. Situations in novels that she had read lent their smooth probability to the raw and disjointed circumstance; she found herself wondering that it was all so horribly painful, so ugly, so devoid of subtle psychological interest and large bearing; not realizing that in actual life feeling is born first, help- 
less as a blind puppy, and philosophy is not born at all, but is built, with infinite selfconsciousness.

She was already on the engine-it was moving; she was holding on to an iron rail as she stood, and was not unaware that it was spoiling her gloves. Major Bunbury's conversation with the engine-driver had ended with an almost imperceptible glide of the latter's hand into his trousers pocket, and Major Bunbury himself was standing beside Slaney in the cramped space available for them, looking preternaturally cheerful and unaffected. He possessed that gift of trivial observation that is the parent of tact and is one of the rarest of male attributes. It can be formidable, it can also be attractive beyond most other things. He hardly looked at Slaney, who was gazing straight ahead through the bull's-cye windows, but he knew that what she saw was not so much the wide tumbling waste of moor with its skirting mountains, as the creatious of her own unsophisticated sus- 
picion. The pace of the engine inoreased momently, from a tremulous glide to a clattering rush; every movement of the driver's hand as he heightened the speed was answered by a forward start, like a powerful horse touched with the spur - unhampered by carriage or tender it raced and swung. Slaney held on with both hands, while the wind from the open sides encircled and buffeted her, ardent with heat snatched from the engine fire, bitter with the frost that had turned the bog drains into mirrors for the keen colours of a winter sunset. There was not as yet a signal worked on the line; they must trust to eyesight and pluck for the safety of an engine driven at nearly its best speed; and the strident shriek tore the air incessantly, and each curve or cutting meant a slackening and an instant of suspense before the long vista opened clear, and they were away again with that living bound that thrilled Slaney's unaccustomed heart as only pace can thrill. She began to understand that they were racing against time and luck to 
intercept-what? Could it be to foil the insane impulse of a woman who had lost her head in the terrible discovery that she had a heart?

The miles fleeted past, until the engine and its pent scream burst forth from the clanging walls of a rock cutting, and skirting a lake, entered on the great brown plain of Tully bog. A double line of drains, fed by innumerable cuts, made a herring-bone pattern on either side; the spongy gravel sprang beneath the strides of the engine; the water in the drains flapped and washed in sympathy against its peat walls. It seemed a singular audacity of engineering to force a line of rails across such a morass. Three miles away the heights of Cahirdreen were dark in the evening sky; recognizing them, Slaney felt the influence of an evil fate cross her keen excitement like a cold streak-like a shiver across the heat of ferer. The driver looked at his watch, and, with one hand on the brake, added the last possible five miles an hour to the pace. 
The engine seemed to be swallowing the endless strip of line that flowed into its clutch; the motion felt like sliding on a wire, without effort or possibility of stopping. Thundering along an imperceptible curve, they neared the hill, with its firtrees ranged in tall and quiet ranks in the twilight. At a distance of perhaps two hundred yards, the cutting opened before them as they rounded the bend, and all four uttered a simultaneous exclamation. The $\mathrm{V}$-shaped cleft held a dark obstruction.

Instantly, with a jar and a jerk, the brakes were on at their full power, and Slaney was leaning back as if to hold off the shock that was already sending shoots of anticipation through her feet and fingers. Shouts, and the whistling of another engine came through the noise, the brakes bit, and shoved, and clung. Somewhere in the jolting, deafeuing seconds an arm came strongly round Slaney's waist, and drew her towards the footboard. She understood that if the worst came she was to jump with Major Bunbury; 
then another hand caught her skirt, and pulled her back. She recognized the driver's filthy white sleeve, and at the same moment some one shouted that they wore safe. Squeaking, and grinding, and skidding, the engine was fought to a standstill, while yet ten yards separated it from the buffers of the brake van in which Lady Susan and Glasgow had started an hour before. Fifty yards further on, the line was blocked by a great pile of gravel and rock, newly fallen from the side of the cutting.

Lady Susan and Glasgow were there; her face looked wild and white, and as she came to Slaney, she seemed to struggle to speak. It was a moment of extremes and exaggeration in feeling. Slaney felt that two independent currents of supreme and foreordained evil had made their onslaught, and, in meeting, had neutralized each other. 


\section{CHAPTER $\mathrm{X}$}

Mr. Glasgow's brown hunter, Solomon, had not lived his thirteen years in vain. When he was led out into the yard one idle forenoon, and was there walked and trotted up and down in front of his owner and two strange men in tight trousers, and when, later, one of the strange men, who had the knowledgeable light fingers of a vet., passed his hand down his legs, and looked into his eyes, and pinched his throat, Solomon knew that it looked like his fifth change of owners. Afterwards he was taken out and cantered in a field, and though he felt chilly and dull, he jumped a trial bank with selfrespect, and with the consciousness that he was giving a lead to the chestnut, who did 
not understand the principle of jumping in cold blood.

He was not mistaken in the purport of these things. Glasgow felt a pain about his throat as he saw the old horse walk into his stall again. He had not thought he would have minded so much. He stood by in the silence that characterizes horse-dealing, while the chestnut underwent examination, and looked round the yard at the miscellaneous collection of wreckage from his railway contract-the broken pumpingengine, the automatic crossing-gates that would not work, the corrugated iron hut that the men would not sleep in-and said to himself that the luck had been against him. It did not occur to him that he had shouldered his competitors out of the contract by a tender that left no margin for mistakes. Mr. Glasgow never made mistakes, but he had based his brilliant and minute calculations on the theory that the cheap Irish labour would accomplish as much in the day as the costly English, and 
the fact that it had not done so was obviously beyond the sphere of rational calculation. In the long stable at the other side of the yard a heavy hoof was dealing sledge-hammer kicks to the stall, and Glasgow, as he heard it, estimated what price the creditors would get for the big dray-horses that he had brought over from England for the railway work. When he thought of the value of the plant that he was going to leave behind, he scarcely felt like a defaulter : there would be more than enough realized to pay the men, and the Railway Company could afford to lose. There remained to him his private means, the Argentine Republic, his own considerable gifts as a civil engineer, andWould Lady Susan remain? He felt little doubt about that part of his future.

Mr. Andrew Murphy was offering him, in the accents of Tipperary, a hundred pounds for the two horses-seventy for the chestnut and thirty for old Solomon-and he was holding out for a hundred and 
twenty with his usual decision. If there were a weakness in his business dealings, it lay in his determination to be decisive at all points. The small and deliberate methods of expediency were intolerable to him; he would rather do without bread than accept the half-loaf. Now, even while each trivial episode was tinged with the reflected light of his future, and all were converging towards an immediate crisis, he held to his point, and had not Mr. Murphy known of an immediate customer for Solomon, the bargain might have ended untimely. As it was, the two horses changed hands at Mr. Glasgow's price, with the understanding that both could be hunted next day by their former owner. Mr. Glasgow insisted on this point, and took all risks.

When it was all over, and Mr. Murphy and the vet. had had whiskies-and-sodas and gone away, Glasgow went back to his office and took up again his task of burning and sorting papers. Being habitually 
orderly in his habits, the work went steadily, and, to all appearance, without effort; yet, as the time went on, his pale face became jaded and grey, and the lines about his mouth deepened.

The terrace at French's Court witnessed that afternoon the least dignified of earthly sights - the struggles of a lady-beginner on a bicycle. It was somewhat of a descent from the heroics of forty miles an hour on an engine, yet as Slancy, flushed and dishevelled, wobbled to her onc-and-twentieth overthrow, the past and future were forgotten in the ignoble excitements of the moment. Major Bunbury, himself in no mean condition of heat, picked her up out of a holly-bush and started her again; he had been doing the same thing for half-anhour, but it had not seemed to pall. When the two-and-twentieth collapse had been safely accomplished, Slaney confessed to feeling somewhat shattered, and returning to the hall, sank into a chair, with aching knees and hands seamed with gravel. 
"It's nothing to what you'll feel like to-morrow," said Major Bunbury, encouragingly. "You rode into the pillar of the gate so very hard last time." He looked down at her from his position on the hearthrug, and then glanced across to the dusky, comfortable corner where the piano was. "I wonder if you remember that you said you were too tired this morning to play that Impromptu?"

"My hands were, and are, permanently hooked from holding on to the rail on the engine," said Slaney, whose spirits had risen as surprisingly as her colour with her first experience on the bicycle, "and no one with a proper sense of how things ought to be would have expected me to do anything but lie on the sofa and faint. Instead of which, I am asked to sit on a music-stool and humiliate myself by playing things that I don't know."

"I think Susan looks more knocked out of time than you do," remarked Bunbury, after one of those comfortable pauses that 
mark intimacy, "and they really had not so near a shave as we had. They weren't going anything like our pace when they saw that the cutting had fallen in." Another pause. "By the way, did youdid you understand that I thought we should have to jump, that time that Ithat I put my arm round you?

"Oh, perfectly," said Slaney distantly, and blushed with fervour. "Mr. Glasgow did not seem to mind missing his train, after all," she went on, speeding into the topic she most wished to avoid, as is frequently the fate of those who talk for the sake of changing the conversation.

"I believe that was all a mistake. Glasgow hadn't the slightest idea of going; he only wanted to see one of the directors who was travelling up by the mail," said Bunbury elaborately.

"Susan waited for us at the station till she was frozen," continued Slaney, taking her share in the apology. "She would have come on our engine only 
that it would have spoiled her box cloth coat."

"Do you know where she is now?" asked Bumbury, after another silence.

"She said something about going to look for daffodils. I saw her going up the backway towards the woods some time ago."

"Are you too tired to walk up to meet her? You may choose between that and playing the Impromptu."

They went up the hill at the back of the house by a seldom-used avenue, where cartwheels had made deep brown ruts in the grass, and the bordering oaks hung their branches low and unpruned; pale winter pastures spread on either side, and the cattle were already moving downwards towards their night's lodging. Yet the hint of coming spring was in the lengthened afternoon; stiff-necked daffodil buds were beginning to bend their heads and show the hoarded gold through the jealous green, and thrushes were twining a net of song in the shrubberies below. It is in the days of 
February that the Irish air begins again to breathe suggestion-no longer mere food for the lungs, it invades the heart, and bewilders the brain with griefs and hopes. Even to the dimming of the eye that smell of the fields entered into Slaney; with a new and strong understanding of herself she could have wept for the guileless egoist who had been Slaney Morris when last the February winds blew sweet.

"Have you written that letter to say that you are not going home to-morrow?" said Bunbury, as he held open the gate that admitted them into the wood.

He had realized during his walk up across the pastures that days in which Slaney had no share would be strangely meaningless. Not being introspective the discovery was sudden enough to set his blood beating and his heart instinctively aching. He knew that she could look forward to days without him as unconcernedly as she would look back to days with him; she was selfsufficing, as the ideal ever seems to be the 
idealizer, and such as he had no portion beyond the opening of gates for her to pass through. Major Bunbury's elder sister must have faithfully fulfilled the mission of elder sister's, or else his natural estimation of himself was low.

"No," replied Slaney, with her eyes on the ground, "after all, I made up my mind not to write."

"Your mind was made up the other way when you talked about it after breakfast," said Bunbury, looking down at her as she flicked a fir-cone aside with her stick. "Do you generally change it every few hours?"

"Emerson says that consistency is the hobgoblin of small minds," replied Slaney, with a little sententious air that Bunbury found exasperatingly charming.

"Does Emerson say that Uncle Charles is a hobgoblin for small minds, and could very well look after himself for another week?" There was a resentment in Major Bunbury's voice that he did not try to conceal. 
"He says nothing of the sort. He might have said Uncle Charles was a Diocesan Nominator, only he forgot to," said Slaney, still preoccupied with the carpet of pineneedles on which they were walking. "But as you're not an Irishman," she went on, "I suppose you don't even know what that is?"

"It seems to be a thing that requires a great deal of unnecessary attention, and can't take care of itself," said Bumbury gloomily.

"Well, you're quite wrong," replied Slaney, looking up with a laugh that was shy and friendly, and a little conscious. She was not accustomed to finding that her comings and goings were of importance to people like Major Bunbury. "It's a most self-sufficing and useful thing. It goes away at intervals to elect clergymen for the Irish Church, and it sent over a note this afternoon to say I was not to go home for two or three days."

Bunbury was quite silent for a few 
moments; then, while the pine-needle carpet seemed to rise up under his feet, he took her ungloved right hand, and raised it, stick and all, to meet his face as he bent over it, like a man stooping to drink. $\mathrm{He}$ kissed it, hurriedly and awkwardly, but in an instant the fine and slender fingers had escaped from his lips, and he stood by her, speechless and dizzy. In that moment of silence his heart opened and let in her dearness like a flood; before the next could dawn with its possibilities, a woman's voice broke out of the wood, through twilight barred with tree stems. It was so near, it was so whetted with agony, so flung about with gusts of passion, that, for the moment, oblivious of what had just passed, they stared at each other for the space of a longheld breath, and were carried on towards it with that instinct that drags every human being towards suffering. A smell of wood-smoke drifted lightly in the air; it strengthened as a bend of the path straightened before them, till they saw 
among the trees a group of men, a fire of fir-branches crackling in a bed of red ember and white ash, and down at the left side of the path a pond that glimmered darkly in a pale- setting of sedgy grass. There was a punt on the pond, and boathooks and ropes were flung about. Glasgow was standing by, why or how it did not occur to Slaney to inquire. There were several countrymen whom she recognized, and all seemed silently intent on some central catastrophe.

The woman's voice was unintelligible now, half-smothered and near the ground, as if her mouth were laid against the grass. Two men stooped and tried to pull her to her feet. A red head appeared, swaying, as when, a month before, Maria Quin staggered through the drunken crowd while they closed her father's coffin. Slaney saw now what it was that lay on the ground beside her; the fixed sprawl of the limbs in the soaked clothing, the discoloured cheek, torn by boat-hooks; it expressed 
with terrific completeness the hunted life, the lonely act of death that had attained such peace as this stillness might betoken.

Tom Quin's black-and-grey dog moved restlessly round the body of his master, sniffing closely at the face, trying to turn over with his nose the rigid hand that still clutched a fragment of sodden reed, in that dumb distress and fear of death that animals must bear uncomforted. Slaney dragged her eyes from the engrossing horror of it, and in doing so met those of Lady Susan at the far side of the group; but nothing seemed strange to her now, not even the white fixity of Lady Susan's face, that told of a plucky woman strongly moved.

At that instant Maria Quin broke out of the group and confronted Glasgow, eyes and face and voice beyond all control or desire of it, and repellent as human frenzy must inevitably be.

"If it wasn't for the way you had him persecuted," she yelled, "he wouldn't be thrown out there on the grass undher yer 
feet. 'Twas you refused him the money back and dhrew the curse on him till ye had him wandhering the counthry night and day like a wild goose. Couldn't annyone know the crayture's heart was broke whin he threw the scafflin' off him and left it on the stone by the brink? Oh, God and His Mother! He knew he couldn't dhrown if that was on him"-she held up the scapulary that Quin, like most Irish Roman Catholics, wore round his neck, and shook it in Glasgow's face- " and you to come walkin' through the woods with yer lover, so quiet! That yersel may be lookin' for a place to die and be threw in a grave that won't be blessed!"

There was a general stifled exclamation, and a man said audibly-

"The Cross of Christ be between us and harm!" One of the French's Court workmen caught at Maria Quin's arm as if to silence her; another pulled him away, telling him in Irish that the curse might fall on any one who interfered with her. 
Lady Susan passed quickly round the outside of the group and came straight to Bunbury, her figure in its brilliant modernity . accentuating the sombreness of a tragedy of this archaic kind.

"I'm going home," she said indistinctly, and walked past him; "I feel rather queer from seeing that___ Her voice failed her, and she put her hand to her eyes. Bunbury followed her without a word. It came home with a pang to Slaney's heart that Lady Susan had turned to him, expecting no quarter from a girl.

She turned to follow them, but she had not gone more than a few yards when she heard a step behind her. Glasgow overtook her, and without speaking began to walk beside her; he looked straight in front of him, and something about his movement and the carriage of his head told her that he was entirely absorbed in hot white anger.

"I hope you are gratified at the result of encouraging superstition," he said at last, 
in a voice that told of the inward pressure of feeling.

"It seems to have been more the result of discouraging it," she replied, without attempting to keep out of her voice the antagonism that was in her heart.

"It would be simpler if you said at once that honest or sane people had better give up having any dealings with the Irish," he returned hotly.

"Do you mean English people? They certainly have not been eminently successful so far."

Slaney felt quite cool, and Glasgow wondered how he had ever found her attractive.

"As you are a friend of these Quins," he said, holding his temper back, but not his imperiousness, "I think it would be as well if you advised that woman to take care about what she says of me, as she may get herself into trouble."

He forgot for the moment the trouble that lay ahead of him; yet the strong nervous 
excitement that fed his anger was due to the imminence of that trouble, forgotten or no.

"I think advice would be rather thrown away on her just now," replied Slaney, thinking of what lay by the pool, and of the wet torn face that the dog smelt at; "even Irish people feel things sometimes."

She suddenly became aware of the spring of tears that lies at the back of a shock, and she bit her lip and drove her stick hard into the ground as she walked.

"I can only suppose then," he said, "that you don't object to hearing your friends publicly libelled."

He held the gate of the wood open for her, and she walked through as stiff as a dart. She knew quite well what sentence of Maria Quin's it was that was foremost on his ear, and it was intolerable that he should take his stand beside Lady Susan. Her distrust of him had become so invincible that she felt Lady Susan to be a bird in the snare of the fowler; she could not think of her as a confederate. 
"Can't you realize," she said, at last, " that nothing I could say would do any good now?"

"I see," he sneered, while he sought among his cast-iron theories of women for something that should fit this abnormal one. "You mean that it is no use to hope that a woman will hold her tongue, whether it be to her own advantage or not!"

The long-pent anger suddenly stirred in her, and with it the resolution that had long lain dormant.

"Would it surprise you to hear," she began, with the sensation of coming into the open, under fire, "that a woman has held her tongue about you for some time past ?"

He half turned and looked hard at her. "I have ceased to be surprised at anything a woman may do, but I should certainly like to hear the particulars of such a piece of self-sacrifice."

Slaney hesitated. It was nearly impossible to say it. The twilight was falling and 
the thrushes in the shrubberies below were piercing it with long shafts of rhapsody. Lady Susan and Bunbury were walking under the bare and drooping branches some distance in front.

"Well," repeated Glasgow, "what about this martyr to principle?"

"It was I," she said, and everything around seemed to throb and stand still, like her heart.

"Perhaps you will kindly explain what you mean," he said, very coldly and politely.

"You lent me a book last month-the Fortnightly Review-and I found a letter to you in it, a letter that you had forgotten was there."

He remained silent for a moment, and then spoke with a jerk-

"May I ask who it was from ?"

"A woman."

"You read it?"

"I could hardly help reading it, it was all on the first sheet." 
She looked at him with the courage of an honourable nature owning to what it would self-righteously have despised in another, and he saw the moistness in her eyes.

"Oh yes, I understand that quite well," he replied, with a quickness that did honour both to him and to her.

There was a pause.

"I burned it at once," she added.

"Oh !" There was no shade of feeling in the monosyllable. "I remember the letter you speak of," he went on very quietly; "what I cannot understand is why you have told me of it? I can hardly think it was for the sake of saying something unpleasant."

"It was because I am fond of Lady Susan," she said desperately.

In the silence that followed it seemed to her as though she had thrown a heavy stone into deep water, without hope of result beyond the broken mirror and the flagging ripple. 


\section{CHAPTER XI}

Next morning, while the last of three white frosts was vanishing from the grass, Hugh stood in the hall at French's Court, pinning a bunch of violets into his red coat. Tops and waistcoat, tie and pin, obeyed to a hair-breadth the minute rigour of male fashion in the hunting-field, the violets made their bold yet not exasperating contrast with the scarlet, and Hugh's pale face was almost picturesque in its gay and vivid setting. Taking up his flask, he went to the dining-room and filled it at the sideboard with old liqueur brandy; he poured out a glass from the same bottle, and was going to raise it to his lips, when he heard voices outside the open door. One of the voices was his wife's, and he heard it with 
that sense of severance from her affairs that had been his since he and his gun-cases had reappeared at French's Court the evening before. He was not usually sensitive to social temperatures, but it seemed to him that there was something flat and ungenial about the whole party. Bunbury was spasmodically agreeable, Slaney was silent, his wife was heavy-eyed and listless ; he encouraged and nurtured the bitter conviction that no one wanted him.

"I suppose you're riding Gambler today?" Major Bunbury was saying to some one in the hall.

"No," replied Lady Susan, speaking rather quickly and indistinctly, "I'm riding Mr. Glasgow's old horse, Solomon, you know. He came over last night. I've always wanted to try him."

Bunbury whistled a few bars of a tune, and knocked down things in the whiprack.

"Hugh's riding that grey," she went on ; "it's quite absurd. He can't do anything 
with him, and he only makes an exhibition of himself."

"Oh, the horse is all right now," replied Bunbury, lowering his voice; "he was very green that first day that Hugh rode him."

"Very well," she said, "you'll see. He won't take that horse across two fences today."

Bunbury passed on out of the hall door, and left Lady Susan standing on the doorstep. She looked up at the cold blue and uncertain grey of the sky, and out at the ruffled and hazy sea, the strong light showing lines of sleeplessness about her eyes; then, turning back into the house, she met her husband. She did not suppose that he had overheard her, yet she was aware of something in his lonely face that she did not care to look at. She went to the table and took up her gloves without speaking.

"Hullo!" she exclaimed, " there's a letter here that came for you. I found it on the floor one night, and didn't think it worth 
sending on. Some one has shoved it behind the card-tray."

Hugh looked at the vulgar and rambling handwriting, and mechanically tore open the envelope. It was a letter clearly written in close and crooked lines, and its purport appeared to be a confused complaint of "persecution" received from the hounds in connection with the covert of Cahirdreen. Hugh read on with a frowning brow. In other days he would have asked his wife to come and read it over his shoulder, but that time seemed now very far away.

Glasgow's name appeared in the letter, with more complaints of persecution; he hardly tried to understand what it was all about. All at once his wife's name seemed to leap out from the paper, and to sink back, indelible, irrevocable, linked to Glasgow's by two or three gross and barbarous phrases, by a warning not less crude, by a cumning treatment of the matter as one of common knowledge. There was no signature, nothing to suggest its connection with the 
dead hand that still clutched the broken reed when Tom Quin's body was taken from the pond.

Hugh raised his eyes and looked at his wife, tasting in that moment the transcendent anguish of the mind that once or twice in a lifetime teaches the body what suffering can be. She was buttoning her glove, standing tall and straight in the light from the open door, in all the spotless austerity of her iron-grey habit and white tie. She seemed far out of the reach of accusation, yet, as he took in every well-known line, forgotten things rose up against her in an evil swarm. His belief in her was falling with the fall of a strong and shading tree; he clung to it even as it fell; and all the while she stood and buttoned the glove across her white wrist.

At half-past eleven a misty fog was drifting loosely up from the south-west on the shoulders of the thaw, and the group of riders outside the covert of Cahirdreen began to turn up their collars. It was a small 
group, and an eye accustomed to the usual muster would have noticed at once the absence of Mr. Glasgow; he was one of the people whose presence makes itself felt in all the varied fortunes of a day's hunting. As the minutes passed, and the horses nibbled idly at the gorse in the fence, the dispensary doctor closed the top of his flask with a snap, and remarked facetiously that he supposed business must sometimes come before pleasure, even with railway contractors.

Lady Susan was at a little distance, apparently absorbed, as was her wont, in attentiveness to what was going on in covert. At the laugh that followed Dr. Hallahane's remark, she moved away, and rode slowly along the edge of the wood. She was on Solomon, who had already taken full note of a lighter hand, a lighter weight, and the absence of spurs: he had had ideas about bucking on the road to testify his appreciation of these things, but on finding that Lady Susan had also ideas of her own 
on the subject, he had made up his mind to treat her with respect. She rode on round the top of the covert, and stationed herself on its farther side; Solomon stood like a rock, with his brown roach back humped against the cold mist.

The hounds had been put in at the lower end of the wood, and were working through it, so far without result. As before, when Cahirdreen had been drawn, Danny-O was not to be found when the time came for him to take the hounds through the covert, and the master, on his grey horse, was riding up a track in the heart of the wood, where the mist had as yet scarcely made its way, and the silence dwelt like a spirit. The horse went ever more slowly among the slender stems of the fir-trees, sharing in the lethargy conveyed by the slack rein and the loose leg of his rider, while the hounds were pushing well ahead through the briars and the bracken, leaving Hugh behind. A straggler or two passed him by, with a wary eye on the whip, not realizing, as the house 
dog so readily does, that human beings have preoccupations in which dogs can be ignored.

It was some time before Hugh noticed the fact that there was somebody near him in the wood-a figure moving among the trees at a little distance. The Scotch firs and larch had been thinned out here for sale to the contractor of the new railway line, and the wood was more open. The figure was that of an old man, who seemed to be advancing in a direction parallel with Hugh. Sometimes the misty fog blotted him out, sometimes the grouping of the tree-stems conspired to hide him; he went onward as if fitfully; the moments when he was lost to sight scarcely accounted for his reappearances farther on. He shuffled like an infirm man, yet his progress through the undergrowth was so steady that it seemed as if he were walking on a path. Irritated at length by the persistent espionage, Hugh called to him to ask what he was doing in the covert. He received no reply, and the mist 
crept in between them. When it cleared again the old man was crossing an open space fifty yards away. Hugh noticed the profound melancholy of his bent head, the yellow paleness of his cheek. Even while something familiar about him vexed Hugh's memory, like an evil dream half-forgotten, he appeared to stumble, and fell with outspread arms and without a sound into some unseen hollow or ditch. Hugh pressed the grey horse through the briars and under the branches till he reached the spot; he pulled up abruptly as he found himself at the edge of a disused sandpit. There were a few rocks flung about at the bottom of it, with the briars growing among them; a rabbit came up out of them, and scuttled to its burrow in the sand at the sound of the horse's tread; nothing else whatever was there.

Hugh put his hand to his head and wondered if he were going mad. 'Then, quite unexpectedly, his knees began to tremble, and the breath of the unknown entered into 
him, cowing the conventions and disbeliefs of ordinary life. At the same instant a hound began to throw his tongue in the covert, two or three more joined, and the grey horse turned of himself to get back to the path. As if through a dark atmosphere of foreboding and doom Hugh heard the whimpers strengthen to yells in all the wild and animal and mundane delight of hunting; he moved mechanically on, while the borders of existence became immeasurable about him, and his unhappiness stretched out into all futurity. There was a rustle in the undergrowth near him, and a fox slipped across the path and away among the trees towards the fence that bounded the wood. It was silver-grey, with black ears and paws, its eyes as it glanced at Hugh were like topazes, and seemed full of the cold lore of unearthly things. The thrill went again from Hugh's heart to his throat, and died away in a sickly chill.

"Damn it all!" he broke out suddenly, "what am I afraid of? I'm going to break 
my neck-that's what it is-and the sooner the better."

An old hound came working and yelping up through the dead bracken; she flung up her head with a long shriek of excitement as she crossed the path; half-a-dozen others rushed to her well-known cry, and went streaming past on the line. The grey horse was quivering and hopping from leg to leg with excitement. Hugh could feel his heart beating up through the saddle.

"All right, you devil," he said, turning him through the trees at a trot; "you'll get a skinful of it now."

The bank was blind and high, and the last hounds were struggling over it with difficulty; Hugh rode along it for a hundred yards or so at a canter, with branches hitting him in the face, till he found a place that seemed possible, and sent the horse at it with a cruel dig of the spurs. In three big bounds the grey was at the fence, the fourth landed him on top among briars and furze, and a drop of seven or eight feet 
into a marshy hollow was revealed. Lady Susan's handling had not been lost on the grey; he kept his head up, and jumped out like a stag, landing clear of the rotten ground, and collecting himself in a moment with his eye on the hounds. Hugh sat him loosely and recklessly; what he felt was not pleasure, yet it was not wholly removed from it. He had, at all events, the fierce and bitter satisfaction of taking his weaker nature by the throat, and keeping it down, even to the death that every fibre was expectant of.

One other rider had seen the hounds going away. As Hugh turned down the hill, witl the pack already three fields ahead, he saw through the mist that a lady on a brown horse had got away on good terms with them from the first. It was his wife, on Glasgow's horse. The rest of the field were left at the wrong side of the covert, ignorant of the fact that the fox had gone away, and, from the line that he had taken, not likely to know for some time. 
Certainly Hugh was not in the mood to remember their existence. He took the grey horse by the head and galloped him at a loose stone wall. They were over with a send and a swoop, and Hugh began to lose the cold trembling in his knees, and to feel again the forgotten grip and swing. Somewhere in the back of his heart he was afraid, but sinister clouds of fatalism and heats of jealousy were between him and that latent and irresponsible treachery of the nerves.

The hounds were running hard, down towards the railway, and Lady Susan was going at her ease with them on Solomon. They flashed across it, and Hugh saw his wife ride unhesitatingly at the stark bog drain, that was the only fence of the unfinished line. The old horse jumped it like a four-year-old, and as he scrambled up the embankment Lady Susan looked back: the mist was creeping down the hill, but Hugh knew that she could not mistake the grey horse. He swore to himself that he would 
show her that he was as good a man as Glasgow, his horse as good as Glasgow's; the most primitive and animal of human hatreds had taken hold of him, and was disfiguring mind and face like a possession of the devil.

In a minute the hoofs of the grey were thudding on the railway sleepers, but in that minute the hounds and Lady Susan had slipped away again; he felt that if they got any farther from him he would lose them in the mist. The going was heavy and the banks rotten in the boggy lowlands beyond the line. He took no care to pick his way, but rode wildly through swampy patches and over rocks muffled in furze, in pursuit of the flying shadow that the mist was momently hiding from him. It was not the way to get safely over a bad country. In the next five minutes the grey horse had twice been nearly down, and his white nose was black with bog mud; he had given up pulling, yet he was going at his best, strong and free, and his ears 
were pricked as gallantly as ever towards his work.

They had galloped perhaps three miles, and were bending back again towards the railway; Hugh was nearer to his wife by a hundred yards as he came with a heavy drop into a lane up which the hounds were running, and thundered up it in her wake, neither knowing nor caring where he was. The fact that they suddenly recrossed the railway by a level crossing conveyed to him no sense of locality. He was possessed by the passion to let his wife see that he was not afraid; to leave her and her borrowed horse behind; and, having gained that miserable joy, to be killed before her eyes. $\mathrm{He}$ was as nearly mad as presentiment, physical excitement, and the burning pain of jealousy could make him, and the grey horse was finding it out.

With a heave and a scramble they were out of the lane and over a bank; it was uphill now, in heather and rough ground, and the grey was puffing audibly as he 
answered the relentless spur. The mist thickened on the higher levels, Lady Susan and the hounds were suddenly lost to sight, and, after a minute or two of fruitless galloping, Hugh pulled up and listened, with his pulses thumping and his mouth dry. A curlew whistled overhead, a trembling crescent of sound, then, high up the hill to his left, he heard again the cry of the hounds. He rode to it desperately, skirting a high furzy knoll, and at the other side caught sight of the pack beginning to run fast again after a check, and his wife was still near them. He saw Solomon slip over a bank and ditch with all the seeming ease of a clever horse well ridden, and he cursed him and his rider aloud. The paltry blasphemy went out into the wind and mist, and was swallowed up in their large and pure philosophy, and it had scarcely left his lips when the greyness that blurred the hill-top became thinner as it drifted, and he saw three tall Druid stones stand out against the sky. 
Immediately some remembrance, vague yet urgent, drove its way into the blind and single resolve of his mind. It was grouse-shooting long ago,-the grey horse took down half a loose wall with him as he jumped, and Hugh chucked him in the mouth and hit him-a man had spoken to him that day about something connected with those stones, he had seen that man again lately - quite lately - there was something horrible about it all.-Come up, horse! why the devil can't you look where you're going? - and yet it eluded him. Then it came, like the dart of a snake out of a ruined wall. It was old Dan Quin, who was dead, whom he had seen in the covert; it was Dan Quin who had spoken to him out grouse-shooting; he had pointed to those stones and told him- Oh, God! his wife was within a hundred yards of the place! He shouted her name with his utmost strength. She did not hear him; she was cantering Solomon up the field, and the hounds were crossing a fence above her, 
beside the lean and crooked emblems of the Druids.

The grey horse was blowing and gulping, yet he answered the furious spurring. Hugh shouted again and again, with his eyes straining after his wife's figure; in the white light of that agony he knew his love for her and his helplessness to save her. She turned Solomon at the fence beside the Druid stones; it was a big bank, with withered branches of thorn-bushes masking its outline, and she sent him at it hard. The old horse jumped on to it like a cat, seemed to stagger and hesitate, and they both were gone.

The grey felt his rider relax and sway, but being young he did not understand what it meant: he was nearing a bank that he felt he could not jump, but the dread of the spur was present with him. He did his best, and but for a rotten take-off he might possibly have scrambled over. As it was, his knees took the bank, his hindquarters flew up, and he turned a somer- 
sault, falling over into the next field. Hugh was shot from his back and pitched on his head and shoulder beside the horse. The latter struggled to his feet, but Hugh rolled convulsively to one side with an inarticulate sound, and lay still. 


\section{CHAPTER XII}

There was an air of calamity and yet of Sunday about the Quins' farmyard. The pigs were shut up, tubs and buckets were put out of sight, and Tom Quin's little nephew, in his best frock, spent many hours of blissful autocracy in banishing the fowl from the doorstep to Siberias behind the rick of turf. Very early in the day two stalwart and dapper members of the Royal Irish Constabulary had made their appearance, and from time to time women in hooded blue cloaks made their way along the causeway that skirted the manure heap, groaned, crossed themselves, and entered the house. In a large shed where Tom Quin had often threshed oats and chopped furze, his body had been laid on two tables, 160 
and covered with a sheet, some superstition about the drowned forbidding that it should be taken into the house, lest death might strike another there.

Awaiting inquest, the sheeted figure lay in its hidden awfulness, with the crooked rafters and the sedgy thatch above, and the candles burning at the head and feet in the grey winter air, wan yet ardent, like the flame of faith in the world's cold noonday. Beside the body the widow Quin sat upon the earthen floor, with a black handkerchief tied over her spotless cap frill, and did not cease from the low moaning and weeping of unstanched grief. Sympathizers stood at the door and looked at her, an intense comprehension of her suffering blending itself with the inevitable fascination of the event, and prayers for the repose of the dead. man's soul were offered with a reality in which a sense of the extreme necessity for them was not concealed.

It was nearly twelve o'clock when Maria Quin came out of the house with a cup of 
tea in her hand; she had on her black best dress, and her boots creaked loudly. She said nothing to those whom she passed, but took the cup of tea to her mother, placing it in the reluctant hand that twisted the apron corner.

"Take it, asthore, take it now," chorussed the sympathizers.

"Lave her alone. Don't be lookin' at her," said her daughter, in the hard voice that had remained unshaken through the morning. She closed the door in their faces, and when she presently came out again with the empty cup, smeared with the stain of the poisonous stuff it had contained, all recognized that the first step in the consolation of the Widow Quin had been accomplished.

Maria turned away. Her head ached wildly, and instead of returning to the house, she passed round the end of the shed, and into the field at the back, that the damp wind of the hillside might blow upon her hot forehead. Her face was quite white 
under its sunburn and freckles, except where the skin below the eyes showed a lavender tinge; the eyes themselves had a dry stare in them, yet there was nothing random or ungoverned about her. Grief drives the active to activity, and perhaps the long: toils of the night, when successive candles found her still sweeping and washing in preparation for the wake and the inquest, had saved her from the reaction from her outburst in the wood; perhaps passion is normal and without reaction in those whose hair is truly red.

The wind soothed her aching head, and she went slowly on and sat down on a stone, with the empty cup and saucer in her lap, looking away up the slope to where a ridge of hill was visible through the soft movement of the mist. She did not at first observe that a grey animal with a black muzzle had leaped on to the loose wall that surrounded the field she was in, and was crouching and looking at her intently. It jumped down with exquisite lightness, a 
pale grey fox with a beautiful white-tipped brush, and crossed the open towards the barn where Tom Quin lay. As it did so, Maria saw it, and sprang to her feet, her mouth open and her eyes starting. The cup and saucer fell with a clatter, and the fox, which had seemed disposed to loiter as it passed close under the wall of the shed, glanced back, looked about it, and after a moment of seeming indecision, turned and trotted at its ease up the hill, heading apparently for much the same point as that from which it had just come. Grey as the mist itself, it glided away, till it disappeared among the clumps of gorse, while somewhere overhead a seagull made its unhappy cry.

Maria Quin fell on her knees with absolute simplicity and spontaneity. She was not frightened in the ordinary sense of the word, but she acknowledged the power of the unseen things that had worked together to her brother's undoing, and she cast herself on a higher protection, half doubtful as she was of its right to intervene. As she 
knelt, with her hand thrust in the bosom of her dress to grasp the picture of the Sacred Heart that hung around her neck, the ery of hounds came to her ear; it approached rapidly, and she jumped up, full of a blind indignation against those who, for their own amusement, had wrecked the fortunes of a family, and now came to gallop past the house of death, guided by that grey and ill-omened thing. Half-a-dozen hounds passed her, hot on the line of the fox, with their heads up; they overran it and tried back, then picked it up by the shed as if they were lapping it off the grass, and with whimpers bursting into the firm note of hunting, went away up the hill and were lost to sight amongst the furze. Others followed in their track, and Maria, maddened by their brutal self-engrossment, their cheery and inconsequent voices, ran in the direction from which they had come, with some inflaming idea of stopping the riders who would follow, equally self-engrossed, infinitely more brutal and desecrating. 
As she climbed the first wall, a horse and rider leaped up into view on a high bank some two hundred yards away to her right, near where three thin and slanting Druidic stones were dimly seen through the mist. They dropped down out of sight among a wild growth of hazels. Maria stood stock still; the powers of darkness had outrun her. Neither horse nor rider reappeared. It was stunningly complete, it was terrific and just retribution, but yet-oh, Mother of Our Lord!-the rider was a woman.

The peasant heart struggled in the graveclothes of hatred and superstition, and burst forth with its native impetuousness and warmth. Maria started forward and ran towards the field where the hazels grew. She ran clumsily because of her ill-made boots, but she got over the ground with surprising quickness. She climbed another wall, a strong one with thorn-bushes laid along the top, and was in a small field full of grey clumps of young hazel. She skirted these rapidly, but with care, and once 
jumped across an ugly cleft among the bushes. The hounds were all about her again, but they were silent now, and were hunting to and fro among the hazel-bushes, and leaping backwards and forwards over rifts in the ground similar to that which Maria had just crossed. Before her was the high bank, showing above a long strip of hazel scrub; she thrust herself, breathless, in among the thick and sturdy growth, her eyes dilated with apprehension, her red hair falling loose in the wind. A cry for help arose at her step, scarcely three yards away; she broke her way to it through the crush of young branches, and saw, as if coming up out of the ground, two gloved hands, clutching all they could hold of twigs and saplings, that bent lithely with the weight that hung from them.

Lady Susan was hanging over the verge of a deep and wide cleft, masked on one side by hazels and briars; her face looked up, deeply flushed, and distorted from the whirl of the terrible moments that make a 
vortex round death, yet it was obvious that even in that extremity she had not lost her presence of mind. Maria dropped on her knees, and twining her left arm round a strong stem, stretched down her muscular right hand. Lady Susan could not let go and grasp it, and Maria caught her by the wrist and drew her slowly upward. There was a struggle, and a tremendous strain on the arms ; both women kept steady and firm, and Lady Susan got her knee over the edge and fell forward on to Maria's shoulder. Her hat dangled by its guard, her habit sleeve had burst away from the shoulder, her patent-leather boots were cut and scraped by the crevices in which they had searched to find a footing; she drew hard breaths in the effort to recover herself.

"Is the horse killed?" she said hoarsely, scrambling on to her fect and looking down through the naked branches that fringed the long cleft.

Even the first glance could certify that Solomon had met his death in an instant. 
He lay in a heap in the obscurity forty feet below, on loose rocks among dark water; his head was doubled under his chest at an impossible angle that told the tale of a broken neck. The uttermost effort of a good horse had not been enough to save him, when he had tried to jump out from the top of the high bank across a chasm nearly twenty feet wide. That endeavour and all his simple and gallant life seemed expressed in the wreck of strength and intelligence that lay below, with the water washing over the flap of the saddle, over the shapely brown fetlocks, over the thin and glossy mane.

It was mysterious water, an underground stream that slid out of the dumb and sightless caverns of the rock, and passed away into them again with a swirl, a stealthy swift thing, escaping always from the eye of day, and cating the foundations of the limestone walls that sheltered it.

Lady Susan still held the hand that had rescued her; it led her through the brush- 
wood to open ground, till the short wet grass was under her feet and the mist blew in her face. She turned her head away, and the sobs broke from her. Any one who has loved horse or dog will know how and where they touch the heart and command the tear. Let us trust that in some degree it is known to them also, that the confiding spirit may understand that its god can grieve for it.

Maria Quin looked at Lady Susan with eyes that were as dry as glass. The Irish peasant regards the sorrow for a mere animal as a childishness that is almost sinful, a tempting of ill fate in its parody of the grief rightly due only to what is described as "a Christhian"; and Maria's heart glowed with the unwept wrongs of her brother.

"What happened him?" she asked, and the knot of pain and outrage was tight in her voice.

"I tried to pull him back when I saw what was coming," said Lady Susan, with difficulty. "I couldn't stop him; he had 
too much way on. I only did harm. I think he would have got across only for that." She stopped and gulped down the sob. It was dreadful to her to cry before an inferior. "He all but got over, but he dropped his hind legs into it and fell back. I somehow caught those branches just as he was going, and he dropped away from under me, and I hung there. I couldn't climb up. Then you came." She recovered herself a little, and turned towards her rescuer. "I haven't thanked you yet. It was awfully good and plucky of you."

Their eyes met, and it seemed as if till then Lady Susan had not recognized Maria Quin. She visibly flinched, and her flushed face became a deeper red, while the hand that had begun to feel for her purse came out of her pocket empty.

"Little ye cried yestherday whin ye seen my brother thrown out on the ground by the pool," said Maria, with irrepressible savageness, "you that's breakin' yer heart afther yer horse." 
Lady Susan took the blow in silence, and that quality in her that ean only be described as an absence of smallness, dimly appealed to the country-woman, as occasionally through Lady Susan's careless life it had had its effect on women of her own class.

"D'ye know yer way home out o' this?" said Maria sullenly. "If ye'll come with me I'll show ye the short way out into the bohireen below our house." She was beginning to be sorry for what she had said, or perhaps the saying of it had eased her heart. "One that didn't know this field would aisy be killed in it. It's full o' thim cracks, and we have it finced sthrong from the sheep." She turned and pointed to the tall Druidic stones. "While ye live ye'll mind yerself whin ye see thim. I thought every one in the counthry knew this place. But sure what are you but a sthranger!" She said it more kindly, and as if explaining the position to herself.

"Look here,". said Lady Susan suddenly, 
"I want to tell you that I don't deserve this kindness from you, and I'm truly sorry for all that has happened about the hounds. It won't happen any more. Will youwill you accept my regret for anything I have done to annoy you, and my sympathy about your brother? I didn't understand how things were_-"

"Oh, God help ye!" broke out Maria, "what does the likes o' ye undherstand about the likes of us? It wasn't wanting to desthroy us ye were, I know that welland faith! I think ye have nature that'd make ye sorry if ye seen my brother this day where he's lying beyond. I know well the one that have no pity; maybe he'll be in the want of it yet." She took Lady Susan by the sleeve, staring at her as if taking in her good looks. "Mind yerself!" she said in a whisper; "that fella would throw ye on the roadside whin he'd be tired o' ye. Don't be makin' little o' yerself with the likes o' him-you that has a good husband and nothin' to throuble ye. I can 
tell ye of the day I wint to Glashgow to the office, axing him to take back the price $o$ 'the land, and he put a hand on me to kiss me; he thought that was all he had to do to humour me. He remembers that day agin me yet. It couldn't be that you, that might be talkin' to the Lord Left'nant or any other, would bring sorrow on yerself for the sake of him."

Neither the straining misfit of the black dress, nor the atrocious pretensions of the cheap boots, could impute vulgarity to the speaker. Lady Susan kept her eyes on the ground with a firmly-set mouth, and Maria turned away in the direction from which she had come. She was overtaken almost immediately.

"I am going back the other way," said Lady Susan. "I'm afraid my husband or some one may be coming this way and not know of this place, and I must tell them where the hounds are, but- Goodbye." She put out her hand in its torn glove; it was still trembling from exertion. 
There was a moment's pause, and the country-woman's hard, red hand took it and shook it, and dropped it.

Neither spoke, but some thrill ran home to Maria's heart with the meeting of the palms, and sent the dew to her hot eyes. They separated in silence, and Lady Susan, following the long cleft to its termination, climbed up the bank. Looking back, she saw the hounds still hurrying in and out among the hazels in excited and fruitless search, and beyond them Maria's black figure going away into the mist and fog. She walked uncertainly, and once or twice her hand went up to her eyes. 


\section{CHAPTER XIII}

As Lady Susan scrambled down the other side of the bank she said mechanically to herself that Hugh must have taken another turn before they crossed the railway, only for that she would have seen him when she looked back before she rode at her last jump. How extraordinarily well he had been going-how long ago it seemed, and yet it could only have been about ten minutes. Below her stretched the long fields up which Solomon had carried her; the mist swept thick and cold across them, shutting out the rest of the world, and making their loneliness more complete. A grey horse was moving up the field towards her; she walked uneasily towards it, crippled by her safety habit, stiff in every limb. 
She could at first only make out that it was lame, she neared and saw a saddle and dangling reins. The stillness of the hillside seemed to tell her the rest. She came up to the grey horse and took him by the head; he was dead lame and trembling all over, there was mud on his jaw, on his shoulder, on the saddle. She had seen before what horses looked like after a bad fall. She led him down the field in the direction from which he had come, and saw, away by the fence, a motionless spot of scarlet and white.

In a few moments she was on her knees beside her husband. His face was buried in a heather tussock, his hands were clinched in the black and boggy soil ; as she tried to turn him over the blood trickled heavily from the corner of his mouth. A little gurgling sound in his throat told her that he was alive, but he was far away in that trance of physical defeat in which soul and body seem alike absorbed.

She was wholly unversed in illness, un- 
acquainted with death, but in the novels she had read episodes of fainting had been freely scattered, and they had left a general idea in her mind. With shaking fingers, shaking from her recent struggle and the impact of this latest shock, she unfastened Hugh's hunting-tie and the neck of his shirt, while her sinking heart told her of her own ignorance and loneliness, and the white face remained unmoved. It seemed to have become smaller, and the temples hollow and blue. She took off the glove from the heavy, listless hand, and tried with her unskilled fingers to feel the pulse. It was just perceptible, and at the contact with that thread of life shut up inside the intolerable mystery of unconsciousness, the fear, the paralyzing helplessness began to give way. Something like the clinking of a tin can came to her ear, and she started up. 'Two little girls, with red petticoats over their heads, were crossing the field, and Lady Susan ran towards them, calling with what voice she could muster. At 
sight of the dishevelled vision in top-boots and a man's bat emerging from the mist, the children seemed disposed to fly, but finally came to her. Her heart sank as she saw their hesitating, timorous faces. Could she make them understand? To every request they returned the same whispered "We will, miss," with their lovely eyes cast down in shyness, but half-a-crown and a glimpse of the figure lying by the fence quickened their sense of the seriousness of the matter. They were taking their father's dinner to where he was working on the line, they would run on to Letter Kyle with a note to the doctor, they would send people to help. Their nimble red feet seemed to promise speed; Lady Susan snatched out her pencil-case, but on what was the note to be written? It came to her like a flash that she had seen Hugh put a letter into his breast-pocket before he started; the inside of the envelope would do.

She went back to him, and with a shrinking hand moved the inert form and found 
the letter. As she took it out of the envelope she saw her own name and that of Glasgow ; and in one blinding moment read the sentence that connected them. There was a pause. She looked up and saw the innocent and awe-struck eyes of the children fixed on her as they stood, too frightened to come near the prostrate figure in the red coat. She put the letter into her own pocket, and opening out the envelope wrote on it her demand for help, for a doctor, for a carriage from French's Court. The final "We will, miss," was murmured, the red legs carried the children down the hill at full speed, till the rhythmic clanking of the milk-can died away.

Let her not be blamed if her first thought was for herself and her position. Her sevenand-twenty years, her careless and daring flirtations, and her marriage, had not taught her what it was to be in love. She knew that Hugh was in love with her; it was a comfortable knowledge, pleasant and commonplace as sunshine, and she had no 
more real comprehension of what he might suffer on her behalf than she had of the flames of hell. She thought first of herself, accused in public, accused in private; she put her hands over her face and said she would go away and never come back to French's Court, where the people spent their time in spying and telling these foul, infernal lies. Hughie would believe her anyhow. She would tell him all about it. It wasn't so very much, after all, and he wasn't a bit strait-laced. She took her hands from her face and saw the motionless body flung in the heathery grass, the vacant brow, the strangeness, the terrific pallor. She stood as people stand when the sudden inrush of an idea overwhelms the physical part of them; it had come to her that it might be too late to tell Hughie about it. It sank into her soul, carrying with it the remembrance of her husband standing by the hall door with the letter in his hand. He had read it before he started; he had only spoken to her once 
afterwards, something about the balancestrap of her saddle, but he had not seemed different. She had noticed that he looked ill, and had presently forgotten all about it. The past flowed in on her; his kindliness, his simpleness, his straightness, most of all, that belief in her that was bound up in the deepest heart of an unjealous nature.

The face that lay sideways in the heather began to torture her with its mute reproach; she knelt down beside him, tearless and tense, enduring strong feeling as the undemonstrative must endure it. She bent over him at length, and, as if half afraid, stooped her head and kissed the pale cheek, knowing for the first time the dreadful kiss that is so much to one, so much less than nothing to the other. 


\section{CHAPTER XIV}

IT was a singular piece of good luck that the two children with the milk-can should have met Dr. Hallahan riding homewards down a lane after an ineffectual search for the hounds. It was also fortunate that it being, so to speak, but the third hour of the day, he was perfectly, almost dismally sober. It was barely a quarter of an hour before he was unfastening Hugh's waistcoat and feeling him all over, while Lady Susan stood silently by. She had found water in a ditch, and brought it in her hat; she stood motionless, with her fashionable head bare to the mist, and when Dr. Hallahan looked up at her he was aware that a handsomer and more haggardly-set face had never waited for his verdict. 
"He's badly hurt, Lady French," he said, his brogue rough with compassion for her; "he seems to have a couple of ribs broken, and there's probably concussion too, and it might be a bit of a crush under the horse."

"Oh!" said Lady Susan stonily. Then, her brain travelling slowly on, "Can we carry him between us? He only weighs nine six."

As she spoke she saw that Bunbury, Slaney, and others were hurrying towards them; it did not surprise her, everything seems to be drawn naturally into the suction of disaster.

Afterwards she realized that it was a long time before a messenger returned with a blue counterpane, and other messengers with a couple of rails from a wooden paling. A species of hammock was made, and Hugh was, with utmost care, laid in it; she noticed that Dr. Hallahan told the bearers not to walk in step. Then Bunbury led up Slaney's horse, and told her she must get 
on to it, that she was not able to walk. Bunbury was white and silent; Slaney's eyes were moist, and her voice unsteady. She seemed to Lady Susan extraordinarily kind.

They made her drink some whisky out of his flask, and she rode on after the hammock down a sheep-track, along a bohireen that was like the bed of a rocky stream, into yet another endless bohireen. Slaney walked beside her; they did not speak, but she knew that Slaney was sorry for her. It made her quite sure that Hugh was dying.

"Where are the hounds?" she said suddenly. "Are they killed too?"

"Dan's got them," Bunbury answered; "the fox went down one of the clefts in that field, and Fisherman and Mexico went after him. The others are all right."

Lady Susan rode on in silence, and Bunbury, leading his horse, walked by Slaney. It was quite unnecessary that he should walk, yet Slaney understood.

They neared at length a white house with fir-trees round it; there was a back 
entrance into the lane, and the hammock was carried into a yard where strange lumber lay about; a broken pumpingengine, signal-posts, long white gates.

"Mr. Glasgow's house was nearest," said Slaney, with her eyes on the ground. "Dr. Hallahan is afraid to take him farther."

The back door of the house was open, and they went in, finding themselves in the kitchen.

"Nobody in," said Dr. Hallahan, exploring the back premises rapidly, "and no one here either," opening and shutting the door of Glasgow's office. "Carry him up. I know the house."

The hammock, with its light burden, was engineered up a narrow staircase; as Lady Susan followed, she noticed Glasgow's gloves on the hall-table, his hunting-crop in a rack. They reminded her of all that was now so very far away, they added inconceivably to his reality and yet to his remoteness. Meeting him again would be more difficult than she had thought. 
Dr. Hallahan opened the door of a room on the landing.

"This is a spare room, I think__ he said, and stopped short.

A woman started up from a table at which she was writing, and stared at them. Her hair was straw-coloured, and drooped in nauseous picturesqueness over her coalblack eyebrows; her face was fat and white, her dress was a highly-coloured effort at the extreme of the latest fashion but one; the general effect was elderly.

"I beg your pardon," said Dr. Hallahan, recovering himself ; "we've brought Captain French here, he's very badly hurt, and I can't take him any farther. Perhaps you could show us where to put him-or ask Mr. Glasgow?"

"Mr. Glasgow has left;" the voice was nasal and cockney. "You can take the gentleman into his room for the present, but I'm going to have an auction of this furniture in less than a week. I'm just taking an inventory now." 
Sheets of foolscap paper were scattered on the table, the list of the furniture sprawled over them in large, black, irregular writing. Slaney had seen that writing before; she felt as if she were in a bad dream-a dream that she had dreamt before, one that was both tragic and ridiculous.

"Had I arrived lawst evening things might have been different," went on the yellow-haired lady; "but I missed my train."

Then, with an air that irresistibly suggested the footlights, she moved from behind the table into a clear space in the room. The bad dream culminated; Slaney knew what was coming.

"Perhaps I had better introduce myself," said the yellow-haired lady,-_I am Mrs. Glasgow." 


\section{CHAPTER XV}

Six months afterwards, when the August sunshine was hot and yellow, and the streets of Dublin were in a fever from the crowd of the Horse Show week, a breeze was to be found under the elms by the polo ground in Phœenix Park. It came from the south, where the Dublin mountains were cool and blue; it was sweet with miles of warm grass, and it was nectar to the polo ponies as they were led up and down with twitching tails and soapy necks after their turn of play. The people who had driven out to see the match sat in the shade, while men and ponies wheeled and raced in the glaring heat, and stroke answered stroke, and the ball was worried about in a medley of polo sticks and ponies' legs. 
Lady Susan was sitting on an outside car by the rails, never taking her eyes off the game.

"I call that a brute of a pony," she said, "don't you, Captain Onslow?" to a man who stood by the car. "I mean the roan that my husband is on. Look there" -as the ball went skipping over the sunny sward, with the roan pony and his rider heading the rush after it- "see how he's pulling, and if he gets his temper up he bolts, and there's no holding him. I can't bear to see Hughie on him."

"I don't think you need be anxious about your husband," said Captain Onslow, inwardly a little piqued by this excessive attention to the game and its dangers, " that pony's about the best on the ground when he's properly played, and that's just what is happening to him. Well hit, indeed!" as Hugh turned the ball with a smooth and clean back-hander.

"I don't care," murmured Lady Susan, "I call polo a beastly dangerous game." 
"It's a true bill against Major Bunbury, isn't it?" asked Captain Onslow, presently, lifting an cyebrow in the direction of two people standing by the rails.

"You go and ask them," replied Lady

Susan.

"Does that mean you want me to go away?" Captain Onslow said these sort of things rather well, and he wanted Lady Susan to look at him and not at the polo.

She glanced down at him in recognition. Her glance was charming.

"It means_-" she began. But there came a thundering of ponies' hoofs, a race for the ball with the roan pony getting the best of it again, and Captain Onslow had to do without knowing what Lady Susan meant.

Slaney sat by Lady Susan as they drove back, flying down through the park with that exhilarating swing and swiftness that belong exclusively to the Dublin outside car. The afternoon was more balmy sweet as the shadows lengthened and the coolness came; beyond the beautiful miles of grass 
and trees the western sky was gathering the warmth of sunset; opposite in the east, the brown smoke of Dublin stained the tranquil heaven, and above it a ghostly half-moon stood like a little white cloud in the depths of blue.

There are moments in life when it is given to some hearts to know their own happiness, and to know it trembling. Come what might, earth's greatest pleasure was Slaney's now: she knew it with all the tenderness and strong romance that were hidden in her nature, with all the comprehension of herself that had grown out of a bitter experience. It was a state of mind that seemed incompatible with the prosaic tweed coat-sleeve that rested on the car as Major Bunbury leaned across from the other side; but as he looked at her he understood that the exceeding beauty of the evening had in some way touched her nearly as it was touching him. As has been said, he kept a soul somewhere, and Slaney had found it and entered in. 
"I want to tell you, Slaney," said Lady Susan, expressing the position from her own point of view, "I never saw you look as weil as you do to-day. I'm awfully glad I made you get that hat. It makes your eyes just the right colour."

Lady Susan was beginning to think of getting out of her arm-chair to dress for dinner that night when her husband came into the room. He did not look as happy as a man ought who has hit two goals for his side and has been at the club afterwards to hear it talked about, and he came and sat on the arm of her chair without speaking.

"You don't feel bad after all that play?" she said, taking his hand and giving him that look of solicitude and affection that can be the best thing in the world to receive. "Not I-I'm as right as possible. I can't remember that I ever was hurt."

"I hate you riding the grey to-morrow at the show," she went on; "I shall be miserable all the time. If I were riding him myself I shouldn't remember that there 
was any danger-and I suppose there isn't really-but it's awfully different to look on. I know it's very rotten of me to be afraid, buit you know I did get an awful fright about you-that time."

He laughed. "You mustn't think about all that," he said gently, "that time is over and done with."

There was a pause.

"I want to tell you a thing I saw at the club just now, a thing in the paper__ " $\mathrm{He}$ seemed rather at a loss how to go on. "It was about Glasgow," he said uncomfortably. The hand that was in his became rather stiff. "Poor chap," Hugh went on, "he was-he met with an accident-I meanin fact, he's been killed." There was silence. "He fell down the shaft of a mine or waterworks or something that he was engineering out in the Argentine Republic, and was killed on the spot. It's a ghastly sort of thing," he ended nervously.

She turned her head till her eyes were hidden against his shoulder. "All right, 
Hughie," she said, in a muffled voice, "it's all right. You know I don't mind. Not really. It's only-it's so horrible-and it makes me think of all that time-and what they said of the bad luck, and everything —_"

"Yes, I know," he said, putting his arm round her.

"You do believe me still that I was only an idiot?" she said, looking up at him with the tears in her eyes.

He kissed her.

THE END. 
Richard Clay \& Sons, Limited,

BRUNGWICK BTREET, BTAMFORD GTREET, 6.E., AND BUNGAY, SUTFOLK. 

der Family Library of Veterinary Medicin waings School of Veterinary Medicine Tufts University 200 Westboro Road 

